Policy analysis

\title{
Identifying spatial conservation priorities using Traditional and Local Ecological Knowledge of iconic marine species and ecosystem threats
}

\author{
Mae M. Noble ${ }^{\mathrm{a}, *}$, David Harasti ${ }^{\mathrm{b}}$, Christopher J. Fulton ${ }^{\mathrm{c}}$, Bruce Doran ${ }^{\mathrm{a}}$ \\ ${ }^{a}$ Fenner School of Environment and Society, The Australian National University, 141 Linneaus Way, Canberra, ACT 2601, Australia \\ ${ }^{\mathrm{b}}$ Fisheries Research, NSW Department of Primary Industries, Locked Bag 1, Taylors Beach, NSW 2315, Australia \\ ${ }^{\mathrm{c}}$ Research School of Biology, The Australian National University, 46 Sullivans Creek Road, Canberra, ACT 2601, Australia
}

\section{A R T I C L E I N F O}

\section{Keywords:}

GIS fuzzy-set spatial modelling

Iconic species

Marine Protected Areas

Participatory mapping

Species distribution models

Traditional and Local Ecological Knowledge

\begin{abstract}
A B S T R A C T
Marine Protected Areas (MPAs) can be an effective spatial approach to conservation, especially when they involve genuine consultation that considers the diversity of stakeholders. Participatory mapping and semistructured interviews were conducted with 52 stakeholders and 22 managers and scientists to identify ecological priorities and concerns across a large temperate MPA in Port Stephens-Great Lakes Marine Park, Australia. There were 19 iconic species of fish, dolphins, whales, and sea turtles that were the focus of ecological priorities and stakeholder interactions with the marine environment. Effectiveness of the current MPA management plan for addressing stakeholder priority and concerns, was assessed using GIS spatial modelling that created fuzzy-set species distribution models (SDMs) based on Traditional and Local Ecological Knowledge as well as scientific and citizen-science survey data. These spatial models for the iconic species across the MPA were then overlaid with ecological concerns of the stakeholders to create a spatial understanding of local threats, and priority areas for targeted management. Poor water quality from terrestrial primary sources was the main concern of stakeholders, more so than in-water threats such as poor fishing practices or impacts to iconic species. While local managers and scientists were relatively reluctant to answer interview questions, there was a general misalignment in approaches to iconic species management, especially for mobile and migratory species, and misunderstanding of stakeholder perceptions of threats. Participatory mapping of social-ecological values provides a method for stakeholders and decision-makers to better understand, discuss, and adapt marine spatial management approaches that support a diversity of conservation and management priorities.
\end{abstract}

\section{Introduction}

Marine Protected Areas (MPAs) tend to be designed to protect marine biodiversity via some form of representative areas embedded in habitat principles and the spatial control of extractive activities such as commercial and recreational fishing (Gell and Roberts, 2003; Halpern, 2003). However, the rise in awareness of non-extractive uses and values for the wellbeing of a diversity people (Noble et al., 2019) has led to changes in government policy for coastal estates to be managed for the triple goals of social, economic, and ecological objectives (Douvere, 2008). Often MPAs are designed as multiple-use zones that identify and conserve representative areas of each habitat type, which act as proxies for conserving locally important species and fisheries (Airamé et al., 2003; Bohnsack, 1998; Fernandes et al., 2005). While there has been a tendency to focus on fishery species and extractive activities in these spatial management designs in the past, marine ecosystems support a range of non-extractive social uses (Noble et al., 2019; Voyer et al., 2015). In order to achieve equitable goals for managing marine estates for all stakeholders, there is a need to understand how spatial plans can conserve key species that underpin both the extractive and non-extractive needs of a diversity of stakeholders. In this way, spatial management plans can broaden their relevance and local community support from implementation to subsequent adaptive revisions to address emerging threats to social, economic, and ecological values.

A core challenge for contemporary marine spatial management is developing a spatial representation of species distributions across a vast area of management, which requires integrating an immense amount of data and/or overcoming gaps in data availability for certain species and locations. Local Ecological Knowledge (LEK) and Traditional Ecological Knowledge (TEK) is increasingly being used to overcome this problem, whereby scientific information is supplemented with local understandings of the marine ecosystem (Aswani and Lauer, 2006; Game

\footnotetext{
* Corresponding author.

E-mail address: mae.noble@anu.edu.au (M.M. Noble).
} 
et al., 2011; Teixeira et al., 2013). This information can be gathered via participatory mapping methods with a range of stakeholders to yield multiple levels of information including ecological patterns and processes, as well as social uses, priorities, and ongoing concerns (Baldwin and Oxenford, 2014; Levine and Feinholz, 2015; Sullivan et al., 2015). Using a mix of LEK and TEK, in conjunction with scientific research data and species distribution models, can allow for co-production of knowledge that fills gaps in our scientific understanding, and cooperative development of priorities and concerns for developing or modifying spatial management plans in an MPA framework.

Historically, MPAs have been designed to prevent marine induced threats such as limiting and protecting against extractive activities that can threaten ecosystem integrity and/or affect access and use by a broad range of stakeholders (Halpern, 2003; Roberts et al., 2003). However, there may be a range of threats to these environments that are not limited to on or in marine waters, such as land-freshwater-sea catchment connections, which also need to be identified and managed to minimise potential impacts on the goals of an MPA (Álvarez-Romero et al., 2011; Cicin-Sain and Belfiore, 2005; Stoms et al., 2005). In reality, MPAs often cover large areas, however, and are limited with resources and staff, which make monitoring these risks and threats a difficult and ongoing task. Capturing the perceptions of a range of stakeholders can identify perceived ecological concerns in an area to rapidly prioritise and address these threats, especially when they relate to locally iconic species that underpin multiple activities and values. Given that stakeholders have interests above and below the water across the entire extent of MPAs (Noble et al., 2019), they have the potential to be salient participants with a wealth of knowledge and direct observations of ecological changes beyond the subset of areas where scientific surveys are conducted (Aswani et al., 2015; Berkes et al., 2000; Turner and Spalding, 2013). These stakeholders also have the most to lose in terms of cultural and community wellbeing and the loss of economic livelihoods in relation to the long-term consequences of potential impacts. Giving the stakeholders genuine ways to engage with the ongoing management of the area, can generate trust with management agencies and empowerment as active agents in environmental custodianship and adaptive co-management (Berkes, 2009; Folke et al., 2005). From a management perspective, on-the-ground knowledge and feedback generated via mapping and targeted interview techniques can provide strategic information that helps prioritise areas for management, while helping stakeholders understand the evidence used by management agencies in making decisions and trade-offs in MPA design and management.

Geographic information system (GIS) multi-criteria evaluation (MCE) spatial modelling methods can provide ways to combine both qualitative and quantitative data into decision-support maps to support spatial planning (Burrough and McDonnell, 2000; Malczewski, 2006; Stelzenmüller et al., 2013). Using these systems to create species distribution models has become an important part of designing and prioritising protected area site selections to maximise management outcomes (Franklin, 2010; Guisan and Thuiller, 2005; Merow et al., 2013; Rodríguez et al., 2007). While this approach is increasingly being applied in marine environments (Pittman et al., 2007; Pittman and Brown, 2011; Sundblad et al., 2011), there are many challenges to developing representative species distribution models (SDM) for a given region due to patchy availability of scientific survey data across the full range of habitats (Elith and Leathwick, 2009; Hernandez et al., 2006; Mouton et al., 2010). Such limitations can be overcome using fuzzy suitability modelling to develop SDMs in freshwater (Adriaenssens et al., 2006; Theodoropoulos et al., 2018), terrestrial (Lu et al., 2012) and marine ecosystems (Hattab et al., 2013), and can also be used to assess ecological threats posed by marine aquaculture (Navas et al., 2011), terrestrial invasive species (Costa et al., 2015), and hydrological dam development (Garcia et al., 2011). Fuzzy logic approaches can be effective when combining qualitative and quantitative expert knowledge and data (Salski, 1992; Teh and Teh, 2011; Wood and Dragicevic,
2007) to develop SDMs since the outcomes of developing a fuzzy-set SDM displays data in a continuous interval range from high to low (e.g., 0 to 1 ), and therefore provides ways to compare and overlay qualitative and quantitative datasets. Applying MCE techniques (Eastman, 1999; Malczewski, 1999; Noble et al., 2019) can create an opportunity to add valuable additional spatial information (e.g., LEK, TEK, citizen science) to develop maps that represent known and likely hotspots of biodiversity and ecological threats within a focal region.

Using MCE fuzzy-set GIS modelling to combine species distribution modelling techniques with Traditional and Local Ecological Knowledge (T/LEK) and scientific knowledge, this study aims to develop a spatial model of locally identified priority (iconic) species and ongoing threats. The model outputs will be used to develop management strategies that address a range of stakeholder concerns for marine biodiversity and ecosystem integrity. To achieve this research objective, three main research questions were used to guide the process: (1) what and where are the ecological priorities for Aboriginal Traditional Owners and local stakeholders in the MPA - are they species or other environmental drivers?; (2) where are the dominate ecological concerns in the area that may negatively impact these priorities?; and (3) what are some scientific or management actions that could be used to mitigate these potential threats?

\section{Methods}

\subsection{Study site}

The study took place in the Port Stephens coastal area of New South Wales, Australia, which is currently under spatial management via the Port Stephens - Great Lakes Marine Park (PSGLMP) management plan. The PSGLMP covers $980 \mathrm{~km}^{2}$ and came into effect in 2007. However, there were some changes in 2018 to the no-take areas along the ocean beaches (New South Wales Department of Primary Industries, 2018). The PSGLMP presents an excellent case study site as it includes a crosssection of environments from freshwater lakes, fresh to brackish rivers, a large tidal estuary, offshore islands and reefs, known area for numerous threatened species (e.g., Great White Sharks, Grey Nurse Sharks, seahorses, etc.), and relatively close continental shelf to offshore-facing headlands (New South Wales Department of Primary Industries, 2018). Given this diversity of environments and relatively diverse social uses of the area (Noble et al., 2019), this MPA provides an opportunity to explore a variety of stakeholder perceptions on the distribution of iconic species and areas of ecological concern.

\subsection{Data collection}

Interviews with local stakeholders, scientists, and managers were conducted between September 2016 and May 2019. A total of 74 interviews with 52 local stakeholders (5 Aboriginal Traditional Owners, 10 commercial fishers, 10 recreational fishers, 8 NGOs, and 19 tourism/ recreational user groups and businesses), 9 scientists (7 departmental and 2 consultants), and 13 managers ( 6 state, 3 federal, and 4 council at various levels of hierarchy within each department). Overall, 83 people were interviewed, with9 interviews having 2 people present, but since these participants had similar perceptions, such as co-owners of businesses or were part of the same management department, they were considered one interview for data processing (Doran and Young, 2013). There were 21 female and 62 male participants. Interview lengths ranged from 5 to $176 \mathrm{~min}$, with an average interview duration of 76.6 ( \pm 4.27) min. During the short interviews (5-15 min) with business owners, all essential information was collected before concluding the interview. Multiple stakeholder types were purposely chosen to represent the range of uses and values of the local community and economies (Noble et al., 2019; Potter et al., 2016).

All the participants interviewed for the study were selected to ensure a broad range of backgrounds and perspectives were integrated 
into the study by recruiting from website searches, publicly available government lists, and tourism business information centres. All the water-based tourism businesses, publicly listed NGOs that are associated with the aquatic environment, charter fishers, and fishing clubs were contacted via phone, email and walk-ins to businesses in order to get an adequate and representative sample and to equitably give the chance to participate in the study. Sometimes the snowballing method (Bickman and Rog, 2009; Hay, 2010; Bryman, 2016) was used after each interview to ensure that key informants within the community were not missed. This also helped the researchers ensure sampling saturation was being reached by crosschecking the people that have already been interviewed, and was particualry usefiul in gaining contacts across the different commerical fishing sectors. Care was taken to build transparent relationships prior to commencing interviews with the Aboriginal Traditional Owner participants, which were created by having multiple consultations through meetings and phone calls (e.g., Potter et al., 2016).

All the participants were purposively selected using a criterion sampling method (Bryman, 2016) aligning with the same criteria used in Noble et al. (2019). These are the following four criteria: (i) must live and/or work within Port Stephens estuary catchment in New South Wales; ii) be a key informant, with knowledge and experience with the direct use, and/or values associated with the estuary and marine environment; (iii) come from the highest hierarchal level possible from each sector and/or has had long-term experience in the area; and (iv) be able to reasonably represent the perceptions of the stakeholder group. All of these criteria and level of expert were assessed during pre-interview phone calls or meetings (Davis and Wagner, 2003). During these exchanges, the participants were briefed about what it would entail to participant in the study, the objectives, and the potential outcomes. A participant information sheet about the study and consent form was given prior to the interview via email, when possible, and before the interview commenced. Both verbal and written consent was gained before starting the interview. No incentives were given to participate in the study. All the major town centres surrounding the Port Stephens estuary were equally targeted to get a spatially representative sample. Only managers and scientists that directly work within or have ties to the Port Stephens area were included in the study (excluding the authors of this article). All relevant studies (published and unpublished) that have taken place in the Port Stephens area on iconic species were identified through Google searches, Scopus literature review, or provided by the New South Wales Department of Primary Industries, which were included in the development of species distribution models (see Appendix B and below).

A mixed-method approach was used in the interview process, which included both participatory-mapping methods (Boschmann and Cubbon, 2014; Brown and Fagerholm, 2015; Doran and Young, 2013; Sloan et al., 2016) and semi-structured interview questions (Hay, 2010; Bickman and Rog, 2009; Potter et al., 2016). Semi-structured interviews were used since it ensured all the questions were asked to each of the participants, but allowed for each individual to add as much detail to the question as they felt comfortable and provided a more freeflowing and flexible conversation (Hay, 2010; Bryman, 2016) when discussing the mapping components. The open ended nature of the method help to accommodate the different perspectives, backgrounds, and cultures that were intended and included in the study. All the participants were asked the same set of questions (Appendix A, Table A1), which were carefully designed to ensure consistency across the stakeholders, but were open ended to not lead the participants (Bickman and Rog, 2009). The questions were cross-checked four ways by getting experienced social researchers to check the structure and type, running a pilot with peer groups, having them reviewed by the university's Human Ethics Committee, and then conducting preliminary interviews with the stakeholders. This process allowed for feedback and modification of the questions before proceeding with the interviews. The participants were asked to draw polygons (e.g., circles or squares)
(Brown and Pullar, 2012; Brown et al., 2017) when identifying areas on the hardcopy laminated maps of the area (scale 1:60,000), due to the observed stakeholder preferences to sketch areas in polygons during the preliminary interviews (e.g., protected cultural sensitive information to circle general areas) and to ensure consistency when eliciting contextspecific representations of spatial knowledge (Golledge and Stimson, 1997). Most of the interviews were done in person except seven interviews conducted on the phone with follow-up emails to confirm mapped areas of biodiversity and concern. All interviews, except four, were audio-recorded after receiving written and verbal consent. Interviews were conducted under the approval and constant monitoring of the Australian National University's Human Ethics Protocol \#2016/ 333.

Interviews that were not audio-recorded had handwritten notes to link the spatial and interview data. Spatial data of high biodiversity, iconic species, nursery habitats, and areas of ecological concern gathered during the sketch-mapping interviews were digitally converted and coded using ArcGIS 10.5.1 and transitioned into ArcGIS Pro 2.4.0. The interview audio recordings and handwritten notes were transcribed, which were then imported and coded per interview question and theme using HyperResearch 3.7.5. Each of the interviews were anonymously identified to avoid biases. Data reports were generated in HyperResearch per interview questions for analysis. A mixed-method framework of narrative thematic analyses and descriptive statistics were used (Bickman and Rog, 2009), which was done first across all the stakeholder groups then a more in-depth analysis was done within each group.

\subsection{Data analysis and spatial modelling}

\subsubsection{Species distribution maps}

Traditional and Local stakeholder data (e.g., Aboriginal Traditional Owners, commercial fishers, recreational fishers, NGOs and tourism/ recreational user groups and businesses) were analysed first to explore overall themes in ecological priorities for the community groups, such as environmental drivers of use and value. Iconic species can have profound societal importance ranging from economic value, fishing, tourism, cultural significance, supporting community wellbeing, and tend to create a sense of place (Caro, 2010). For this study, iconic species were identified in the interviews and then tallied. The proportion of species that received $65 \%(\geq 5)$ or more mentions by the participants were considered to be the most important iconic species for the stakeholders. Sketch-mapping data that related to areas supporting these iconic species (e.g., nursery, aggregation and spawning sites, resting and foraging areas, and functional habitats) were collated and used to create an overall map representing the Traditional and Local Ecological Knowledge of iconic species distributions in the PSGLMP. Only stakeholder data collected from the interviews were used in this spatial analysis and only the 19 species identified by the stakeholders were considered in the study. Due to insufficient responses from the scientists and managers regarding iconic species and species distributions during their interviews (only $22 \%$ response rate), only the interview data was used in the study. The T/LEK acronym from this point onwards will be used to represent a combination of Traditional Ecological Knowledge (TEK) and non-indigenous Local Ecological Knowledge.

The T/LEK spatial data were analysed to separate and create individual iconic species index layers, which means 19 T/LEK index layers were produced in ArcGIS Pro 2.4.0. The T/LEK species distribution spatial model map was created using multi-criteria evaluation (MCE) fuzzy-set non-weighted linear combination methods (Burrough and McDonnell, 2000; Jiang and Eastman, 2000; Malczewski, 1999). Each of these index models represents areas of high to low (e.g., fuzzy logic) species distributions by overlaying each of the areas identified by the participant's of the knowledge of where a species is likely to occur, areas of regular access, and any other relevant knowledge (e.g., nursery 
habitats). The polygons of this spatial data were converted into raster format to represent a value of 1 for each of these areas, and a linear membership function (Burrough and McDonnell, 2000) was applied to each polygon to create a fuzzy transition of 1 to 0 (e.g., high to low) across a $100 \mathrm{~m}$ buffer. This fuzzy buffer was applied to support data uncertainty and to more appropriately represent an individual's spatial cognition in dynamic marine environments (Teh and Teh, 2011). Each of these layers were combined to get an overlapping map representing hotspot areas for each of the 19 species (e.g., high to low) using nonweighted linear combination equation: $S=\Sigma w_{i} x_{i}$. $S=$ suitability, $\mathrm{w}_{\mathrm{i}}=$ weight of factor $\mathrm{i}$, and $\mathrm{x}_{\mathrm{i}}=$ criterion score of factor (Malczewski, 1999; Teh and Teh, 2011; Voogd, 1983; Wood and Dragicevic, 2007). To clarify the equation for this study, the following can be considered: $\mathrm{S}=$ iconic species hotspot map, $\mathrm{w}_{\mathrm{i}}=$ proportion of participants layers combined, and $\mathrm{x}_{\mathrm{i}}=$ individual participant rasters with values ranging from 0 to 1.0. Once each of the species maps were created, an overall overlapping fuzzy-set T/LEK species distribution model was created by combining these species maps using the same approach outlined above. See Appendix B, Figure B1 for a conceptual diagram of data flow used to create the SDMs.The mapping outputs were scaled for the best representation of the key patterns within the study area, for the full scalemaps of the 19 species see Appendix B, Figure B2.

Alongside the T/LEK species distribution map, scientific species distribution models were created for each species that were a combination of a base map of likelihood of occurrence based on depth and habitat preferences (i.e., niche model), scientific studies, and citizen science in the area (Appendix B, Table B1). For the likelihood base maps, two maps of depth and habitat were created to be reclassified and ranked on a scale from 1 to 10 , according to the species preferences (see Appendix B for more details). The data that underpinned these rankings were collected from an extensive literature review of a wide range of published sources and research studies (Appendix B, Table B1) with studies from the eastern coast of Australia prioritised. After reclassifying the base map rasters, each was standardised (e.g., divided by 10.0) to generate values ranging 0-1.0. The depth and habitat map for each species were then combined using the same weighted linear combination equation used above to get a fuzzy-set species-specific likelihood map of occurrence that ranged from high to low.

Scientific and citizen science survey data layers were developed for each of the 19 species to add to the distribution models. This was based on a literature review to find published spatially-explicit scientific studies that have occurred within the study area, and publicly available citizen science underwater survey data through Reeflife (Edgar and Stuart-Smith, 2019) or logged occurrence records sourced from the Atlas of Living Australia database (Atlas of Living Australia, 2019) (Appendix B, Table B1). To ensure that the data could be appropriately represented and overlaid with the T/LEK and likelihood base map datasets required that the fuzzy logic (e.g., high to low) hotspots maps needed to be maintained. Therefore, the scientific survey areas used for the polygons were based on the survey method (e.g., 50 meter transects), and the high to low values are based on the combination of data outcomes and type of study (Appendix B, Table B1). Five methods were used to integrate the scientific spatial data (see Appendix B): (1) maps with species sightings and satellite data represented in published figures were imported into ArcGIS Pro 2.4.0 and georeferenced create data layer; (2) raw sighting survey or satellite tracking data were used to create a layer of points, polygons, or polylines; (3) underwater visual survey data sites had polygons drawn to the size of the survey method (e.g., $150 \mathrm{~m}$ transects at 10 meter depth); (4) Baited Remote Underwater Video (BRUV) sites had points added to the GPS locations then a buffer was applied according to the BRUV type; and (5) VEMCO acoustic tagging receiver station data locations were added as GPS points and a buffer was applied with the possible detection range (e.g., $500 \mathrm{~m}$ ) of the receiver. When raw data were available, two layers were created that consisted of normalised abundance and the Coefficient of Variation for each site, that was standardised $(0-1.0)$ and then combined using a weighted linear combination to get an overall ranking of the sites of supporting high to low abundances of each of the species. When the raw data was not available, each of the sites were ranked from 0 to 1.0 (e.g., high to low) according to the results of the study.

Through the process outlined above each of 19 species had a scientific-based index model created using the weighted linear combination equation to combine the species likelihood niche base maps, scientific data, and citizen science layers. These were then combined to create an overall scientific species distribution model with all species assigned equal weightings. A habitat species distribution map was also created due to certain habitats being identified by some of the participants to be iconic or particularly critical for the Port Stephens area. The habitat map was developed by combining three layers: a likelihood base map model (Appendix B, Table B2), survey and monitoring data layer (Appendix B, Table B2), and T/LEK habitat layer was created from areas identified by the participants to be important areas for each of the habitat types. A final overall species distribution model then combined the T/LEK, scientific, and habitat maps using a non-weighted linear combination.

\subsubsection{Ecological concerns}

Interview data were analysed to reveal six key themes in stakeholder perceptions of ecological concerns in the PSGLMP. Local stakeholder spatial data was then processed to identify areas that aligned with the six identified themes: poor water quality, iconic species impact (e.g., seagrass destruction), poor fishing practices, sand movement, litter, and climate change. Managers and scientists were also given an opportunity to identify areas of ecological concern, but due to poor responses rates and overall reluctance to answer the questions, they were given an opportunity to respond to some of the main concerns of the local stakeholders according to their department or research focus.

To align with the species distribution models methods described above (Section 2.3.1), digitised polygons of the stakeholders' ecological concern spatial data were converted into raster format to represent a value of 1 for each of these areas and a linear membership function (Burrough and McDonnell, 2000) were applied to create a fuzzy transition of 1 to 0 (e.g., high to low) across a $100 \mathrm{~m}$ buffer. Stormwater drain locations in the estuary were provided from the Port Stephens and MidCoast Councils, and each site had $50 \mathrm{~m}$ buffer added to each point, and then $100 \mathrm{~m}$ fuzzy transition buffer applied, which were then added to each of the participant layers that identified stormwater drains to be a high concern to the water quality in the area. Additional water monitoring data were collected from various governmental and citizen science sources (Appendix B, Table B3).

Once the ecological concern index layers were created (see the individual T/LEK ecological concern maps in Appendix A, Fig. A1), they were combined and then overlaid with final combined species distribution map (19 iconic species and habitats). Using the Fuzzy Overlay tool in ArcGIS Pro 2.4.0 with the AND function provided an output map of only areas that overlap and have a high value when combined. To better identify these high-value overlapping areas, both the ecological concerns and the species distribution maps were converted into polygons with only the high values from each map selected for output. Using the Intercept Tool in ArcGIS, a map of areas with overlapping polygons was developed, and these were used to overlay with the fuzzy output map to outline areas of potential risk from the stakeholders' perspectives. A matrix was created to explore each of the concerns ranked High $\geq 60 \%$, Med $\geq 30 \%$, Low $\geq 1 \%$, and no concerns for each of the 26 sites with a recommended response from each management institution (Appendix A, Table A3). The same overlapping map was overlaid with the current zoning map to highlight targeted management areas. 


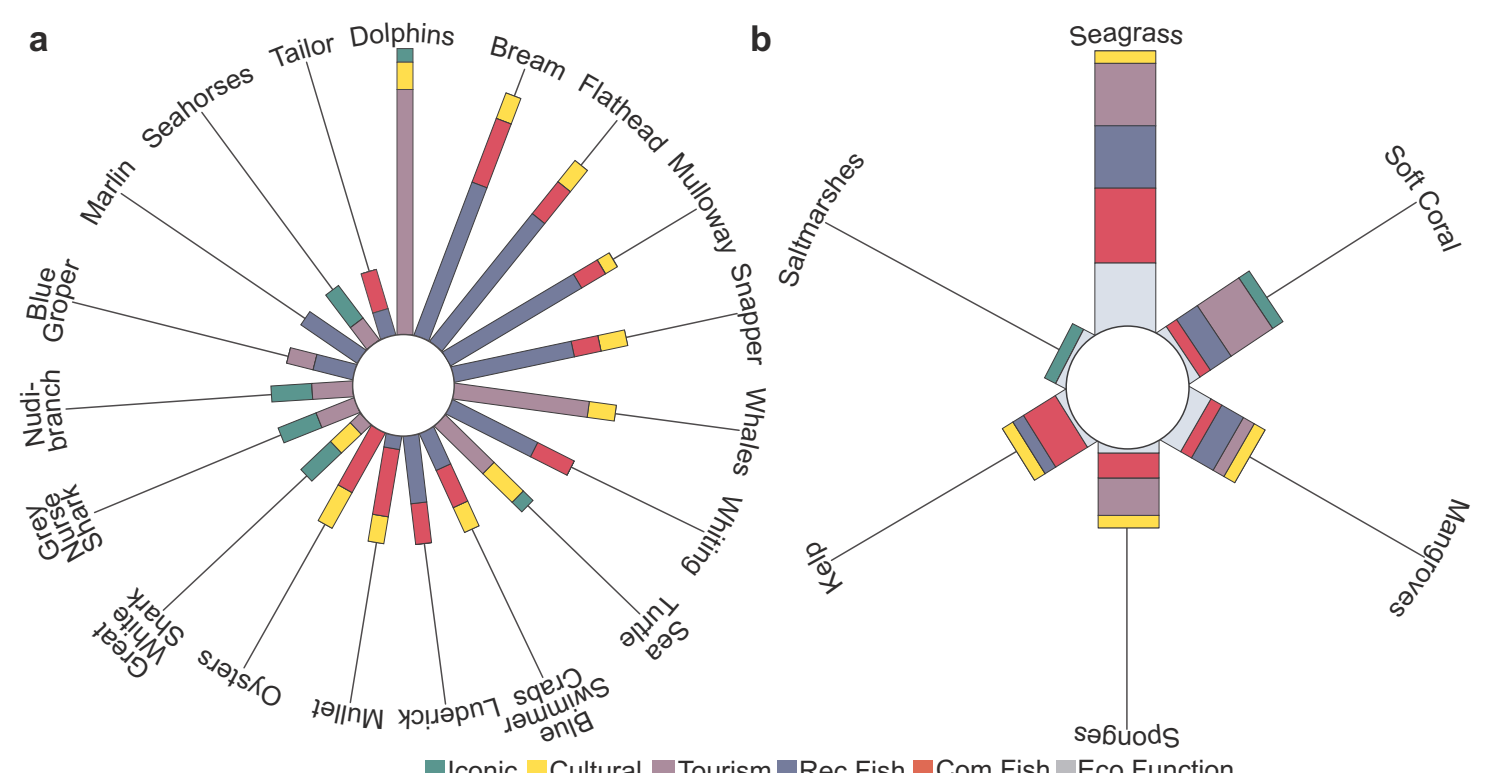

C

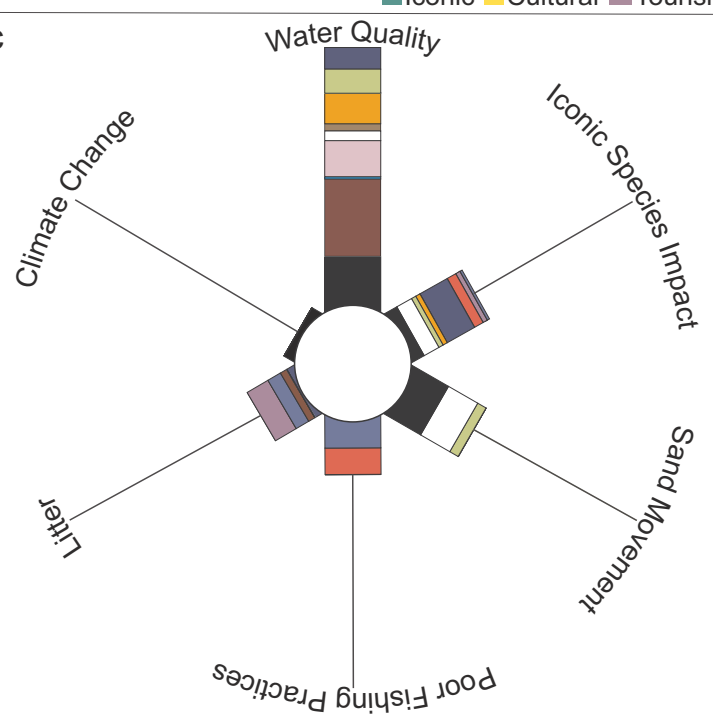

d

Rec Fish $\square$ Com Fish Eco Function

StormW $\square$ RAAF $\square$ Develop $\square$ Mine $\square$ Agricul $\square$ Fish Farm $\square$ Marina $\square$ Boaters $\square$ Tourism $\square$ Indirect

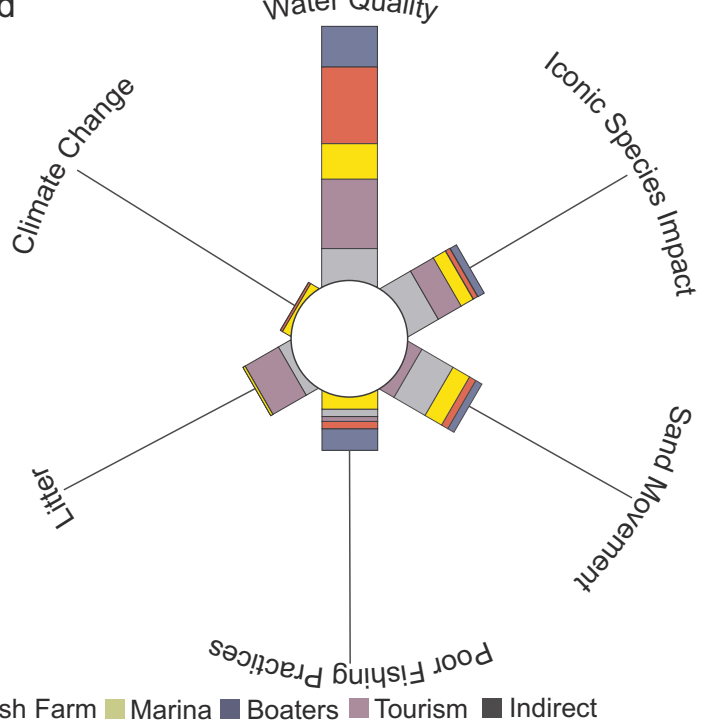

Fig. 1. Proportions (relative length of column per circle) of stakeholders' perceptions for both priority species (a-b) and ecosystem concerns (c-d). Proportion of priority species for (a) the top $65 \%$ of the most mentioned species that were are of direct importance according to each of the stakeholder groups; and (b) the benthic habitat types that were identified to be critical in directly and indirectly supporting each of the stakeholder groups livelihoods and wellbeing, or were mentioned to support broader ecosystem functions. Proportion of environmental concerns that may impact the MPA in (c) what is causing the risk either directly (industries and social groups) and indirectly (environmental responses to disturbances); and (d) who and what will be directly impacted by these risks (social groups) or indirectly (ecosystem function) by the consequence of these environmental concerns. Acronyms: Iconic $=$ species that define the local marine environment or that are particularly special for overall local community wellbeing, Cultural $=$ Aboriginal cultural significance, Rec Fish $=$ recreational fishers, Com Fish $=$ commercial fishers, Eco Function = ecosystem support, StormW $=$ stormwater drains, RAAF $=$ Royal Australian Airforce Base, Develop $=$ development, Mine $=$ coal mines up Karuah river, Agricul $=$ agriculture runoff, Fish Farm $=$ offshore aquaculture pens, Marina $=$ marinas within MPA, and Indirect $=$ environmental responses as a consequence of human disturbances.

\section{Results}

\subsection{Species distributions}

The stakeholders identified two main ecological priorities and drivers that support and facilitate their engagement with the aquatic environment. The primary driver is to access and enjoy species, and the secondary driver is to enjoy being on or under the water. Notably, $92 \%$ of the stakeholders identified 71 species as being iconic, with 19 fauna species (e.g., fish, marine mammals, and marine reptiles) repeatedly mentioned as having particular significance across all of the stakeholder groups (Fig. 1a). These 19 species were identified as essential for supporting economic livelihoods, recreational use, and/or supporting broader cultural and community wellbeing. Species of importance (Fig. 1a) covered a spectrum of use from being the focus of non-extractive (9 species) appreciation (e.g., dolphin watching for the tourism groups) to highly-prized extractive (10 species) targets (e.g., bream for recreational fishers). In particular, six species (e.g., dolphins, sea turtles, Great White Sharks, Grey Nurse Sharks, Nudibranchs, and seahorses) were perceived as being particularly iconic to the area because they were thought to define how people identified their local marine environment and were perceived to be particularly special for these areas. Unexpectedly, some of the stakeholders also mentioned, unprompted, that certain habitats were important and in some cases, iconic for the area (e.g., soft corals, saltmarshes; Fig. 1b). When discussing these habitats, most of the participants were adamant they were 

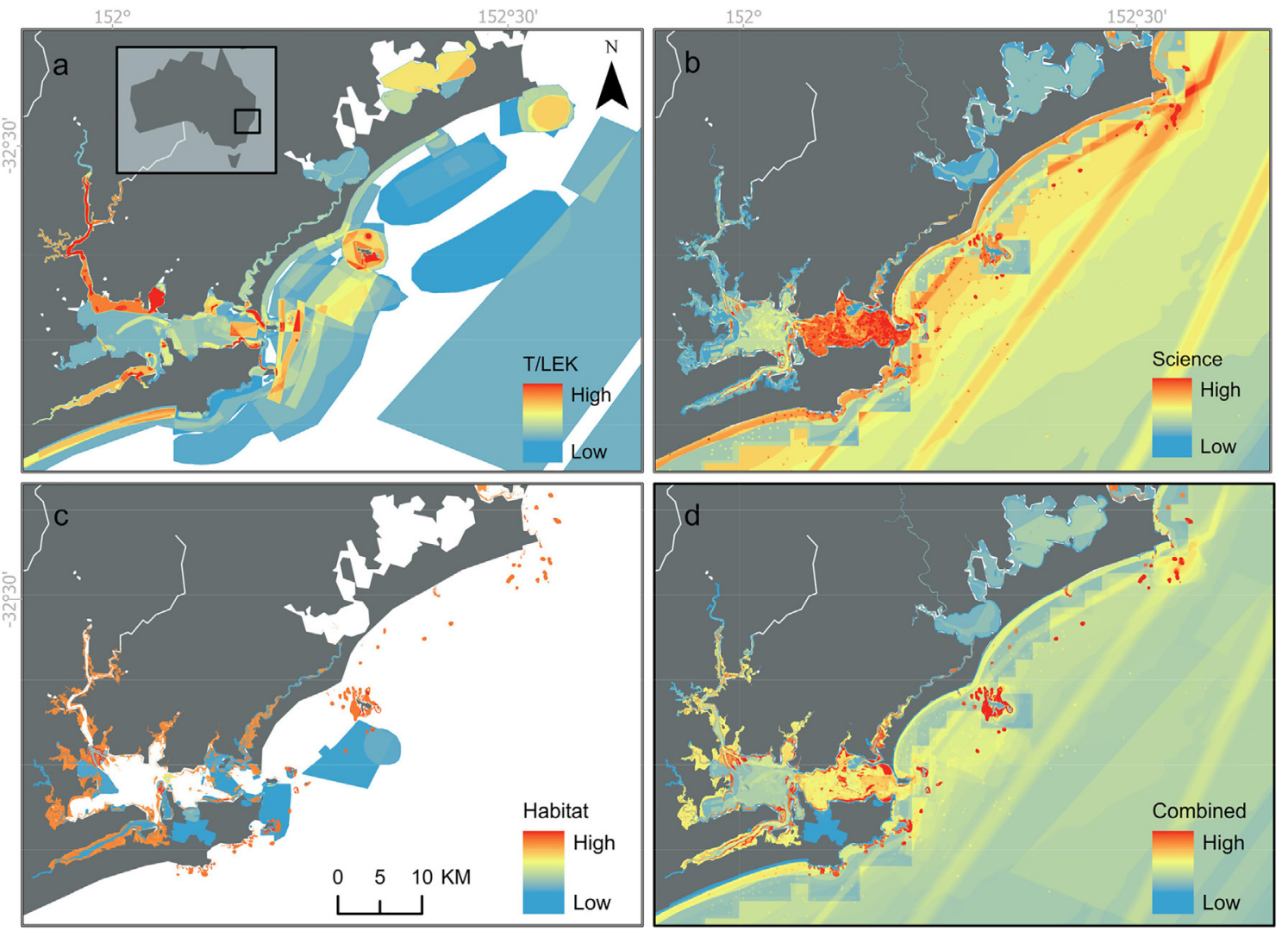

Fig. 2. Maps representing areas that support iconic species (identified in Fig. 1) according to a) local stakeholders; b) scientific-based species distribution models; c) areas of important benthic habitat (LEK and scientific data); and d) final combined model of a-c to highlight areas of significance for both iconic species and important habitats across a range of LEK and scientific evidence (see Appendix B, Tables B1-B2 for more details).

essential in supporting either broader ecosystem integrity or underpinning the sustainability of their stakeholder group use of the environment (e.g., nursery habitat for iconic fauna; Fig. 1b). Interview data from the scientists and managers was patchy when asked about managing iconic species. In response to questions about the lack of prioritisation of certain extractive species in current MPA management plans, a common perception was that some of these species were not able to be protected by spatial management since most were mobile and migratory species (e.g., bream, mulloway) with little control of incoming and outgoing individuals. Prioritisation of management for non-extractive species was also regularly dismissed by managers since it was perceived by this group that fisheries targets were the main focus of the MPA.

Spatial representations of the Traditional and Local Ecological Knowledge (T/LEK) and scientifically base species distribution maps (SDMs) demonstrates varying trends across each of the two knowledge groups (Fig. 2a-b). The differences in the T/LEK map (Fig. 2a) showed that were high species distributions for the 19 identified species in the western part of the estuary, particularly up the rivers (i.e., Karuah River and Tilligerry Creek) and freshwater lakes (i.e., Myall Lake), in contrast to the scientific-based map (Fig. 2b) where most of the 19 species and sampling effort occurred in the eastern part of the estuary. Notably, there were some similarities with both the maps, such as high species distributions surrounding the offshore islands, the eastern and southern shoreline of the estuary, and the northern offshore point (i.e., Seal Rocks). Combining both the T/LEK and science-based habitat maps (Fig. 2c) demonstrate that the upper reaches of brackish/freshwater rivers and tributaries, along with small patches of seagrass, soft coral and reefs (i.e., sponge and kelp habitats), are not evenly distributed across the estuary and offshore. However, as stated in the method section, some of the areas have varying levels of benthic mapping for the habitats, especially in the eastern part of the estuary and offshore. Therefore, these areas could have important habitats that were not able to be considered here. When all three of the T/LEK SDM, scientificbased SDM, and habitat maps were combined, the final map (Fig. 2d) shows small patches of very high species (i.e., fauna and flora) distributions across the PSGLMP. The individual maps of species distributions can be found in Appendix B, Figure B2.

\subsection{Ecological concerns}

Interview data of the stakeholders revelled common trends in the ecological concerns for the marine environment (Fig. 1c-d). The analysis found that water quality issues are proportionally the biggest concern, followed by iconic species impacts (i.e., flora and fauna), sand movement, poor fishing practices, litter, and climate change. Water quality issues were thought to be caused by a range of sources (Fig. 1c), with the main risks coming from terrestrial inputs through stormwater drains, the Royal Australian Air Force base (e.g., PFAS), urban development, and mining. Other more minor issues with poor water quality came from in-water sources such as boaters (e.g., directly dumping effluent), offshore aquaculture fish farm pens and marinas. Interestingly, when asked the question about freshwater inputs as being an issue for water quality (Appendix A, Table A1), most stakeholders were not worried about the freshwater in particular, but generally perceived that the terrestrial run-off that polluted the rivers and tributaries as being the primary source. Iconic species impact was the second biggest concern for the area, with boaters thought to be causing the most issues with moorings destroying seagrass, strikes with dolphins and sea turtles, and creating bank erosion in the rivers with wakes from boats. There were four other ecological concern categories: sand movement, poor fishing practices, litter and climate change (Fig. 1c), and within 
each category there were various stakeholders and industries perceived as being the cause of these issues. In four categories (i.e., water quality, iconic species impact, sand movement, and climate change) the causes for the ecological concern was thought to be an indirect consequence of human interference or impact to the environment.

All of the ecological concerns were perceived to impact the stakeholder groups directly through the potential of the risk undermining iconic species abundance, ruining the aesthetic quality of the marine environment, or presenting a risk to undermine the ecological functions of the aquatic environment (Fig. 1d). Overall, the non-extractive tourism and recreational stakeholder groups were the most concerned out of the five stakeholders' groups, followed by Aboriginal Traditional Owners, then commercial fisheries, and lastly recreational fishers. Some of the stakeholders' language used to describe the concerns helped to demonstrate the long-term risks they might have on the economic livelihoods, recreational access to important species, and the cultural and community wellbeing (Appendix A, Table A2). As outlined in the methods section, the scientists and managers were reluctant to identify specific concerns or areas, and as such, each relevant institution was asked to respond to the applicable ecological concern. The responses varied across the scientists and managers. Overall there was a general dismissiveness, varying levels of scepticism, and misalignments with the stakeholders' concerns (Appendix A, Table A2). There was an acknowledgement that many institutions operate and manage the area, but there are known issues of effective coordination and communication.

Due to the overwhelming concern with poor water quality, two separate mapping outputs were developed to provide a way to identify areas that have perceived and measured high values for poor water quality (Appendix A, Fig A1a) represented alongside the other five ecological concerns (e.g., iconic species impact, sand movement, poor fishing practices, litter, and climate change; Appendix A, Fig. A1b). These two ecological concern maps were then combined and overlaid with the final species distribution map (Fig. 3a) to identify areas that have the potential to impact iconic species and biodiversity. The representative map demonstrates that each of the hotspots (labelled with a letter) supports a range of concerns from the stakeholders and could be addressed using collaborative institutional responses (Appendix A, Table A3). When exploring the relationship of these overlaps with the current spatial plan (Fig. 3b), it creates another strategic management map to identify areas that need to be addressed, whether it should be an application of a spatial zoning planning, use of seagrass friendly moorings, improved compliance/education, places of sand mitigation strategies, and habitat rehabilitation. Also, by highlighting potential problem stormwater drains, these areas could be targeted by combination of management strategies to mitigate poor water quality and gross pollutants (i.e., litter) entering the marine environment (Fig. 3b). These maps could be used to aid discussion to build collaborative networks across relevant institutions and to develop co-management strategies with the local stakeholders. During this process, it was found that eleven institutions had various roles in addressing the concerns in each of these areas (Appendix A, Table A3). Notably, the councils have a considerable role in helping to moderate the water quality, mitigate sand movement, and control litter in the area.

\section{Discussion}

This study demonstrates that marine species are the main ecological priority and the primary driver for stakeholder use and value of this temperate coastal MPA. Mapping areas that support these high priority (iconic) species provided some key insights into the types of spatial management and other targeted management practices that could be most effective in supporting the social and ecological resilience of this coastal ecosystem. About half of the iconic species did not align with the current management priorities for hotspots of concern, despite the likelihood of extractive and non-extractive pressures that could impinge directly (e.g. harvesting) or indirectly (e.g., habitat loss) on each species. The misalignment between current spatial management plans and community concerns may be linked, in part, to the perception of local natural resource scientists and managers that these species are migratory and unable to be spatially protected in the MPA framework. However, these scientists and managers were often unaware of key aggregation/spawning sites, resting and foraging areas, and nursery habitats for these species that were known and identified the stakeholders. Using the spatial methods outlined in this paper to combine multiple sources of evidence, both Traditional and local ecological knowledge and scientific survey data provided an effective means of identifying species and areas of concern, and most importantly, spatial hotspots that should be a high priority for consideration in any future revisions of the MPA spatial management plan.

\subsection{Prioritising iconic species distributions}

In designing MPAs, it is common practice to spatially protect percentages of representative habitats that are thought to act as proxies for marine biodiversity and key processes such as population replenishment (e.g., nurseries for fish recruitment; Airamé et al., 2003; Bohnsack, 1998; Fernandes et al., 2005). However, a paucity of data can mean some habitats are not the best surrogates for supporting biodiversity and key ecosystem functions (Rees et al., 2014; Stevens and Connolly, 2004), or some intermediary habitats required for species to complete their life history are overlooked (Agardy et al., 2003). Here, a novel combination of evidence from local stakeholders and scientific surveys, prioritised towards locally iconic species, was employed to develop spatially explicit areas of importance and concern in a diverse and widely used marine estate. The fuzzy-suitability approach (Adriaenssens et al., 2006; Costa et al., 2015; Mouton et al., 2009; Robertson et al., 2004) provided a means to develop SDM likelihood of occurrences based on a combined model of niche depth and habitat for each species in area, and use these as base models to overlay existing $\mathrm{T} /$ LEK and scientific information to identify high priority areas that could achieve multiple conservation and management objectives through targeted protections that span the land-sea interface. Further, this method identified areas that may have been overlooked by past monitoring and management plans. Ultimately, actions that address concerns for these areas provide an opportunity for managers to showcase the role of stakeholder understanding and perceptions for managing biodiversity that supports a broad cross-section of the local community.

Prioritising species to be protected using spatial planning is an important step in marine spatial planning (Roberts et al., 2003). Some studies recommend that using marine spatial plans to protect ecologically functional, threatened, indicator, or keystone species (e.g., habitats and fish) should be the priority of the management practices (Bellwood et al., 2004; Crowder and Norse, 2008; Foley et al., 2010). Notably, it was found in this study, and in relevant government reports (New South Wales Marine Parks Authority, 2010; NSW Marine Estate Management Authority, 2018), that the scientists and managers' ecological priorities did not always align or consider all the iconic species identified in this study when protecting and managing the MPA. However, as supported by this study and others (e.g., Roberts et al., 2003), prioritising certain locally iconic species is critical in marine spatial planning, given that these species will be driving the uses, may experience intense extractive and non-extractive human pressure, and could potentially be impacted on by stakeholder groups in the area. The species (e.g., habitat and fauna) identified in this study underpin Aboriginal Traditional culture, commercial fisheries and tourism economies, recreational fisheries, non-extractive recreational uses, and broader community wellbeing. Therefore, balancing the access to, and prioritising the spatial protection of these species across both the extractive and non-extractive user groups is imperative, especially with the increases in human coastal population and nature-based tourism (Buckley, 2010). Furthermore, prioritising species of particular 

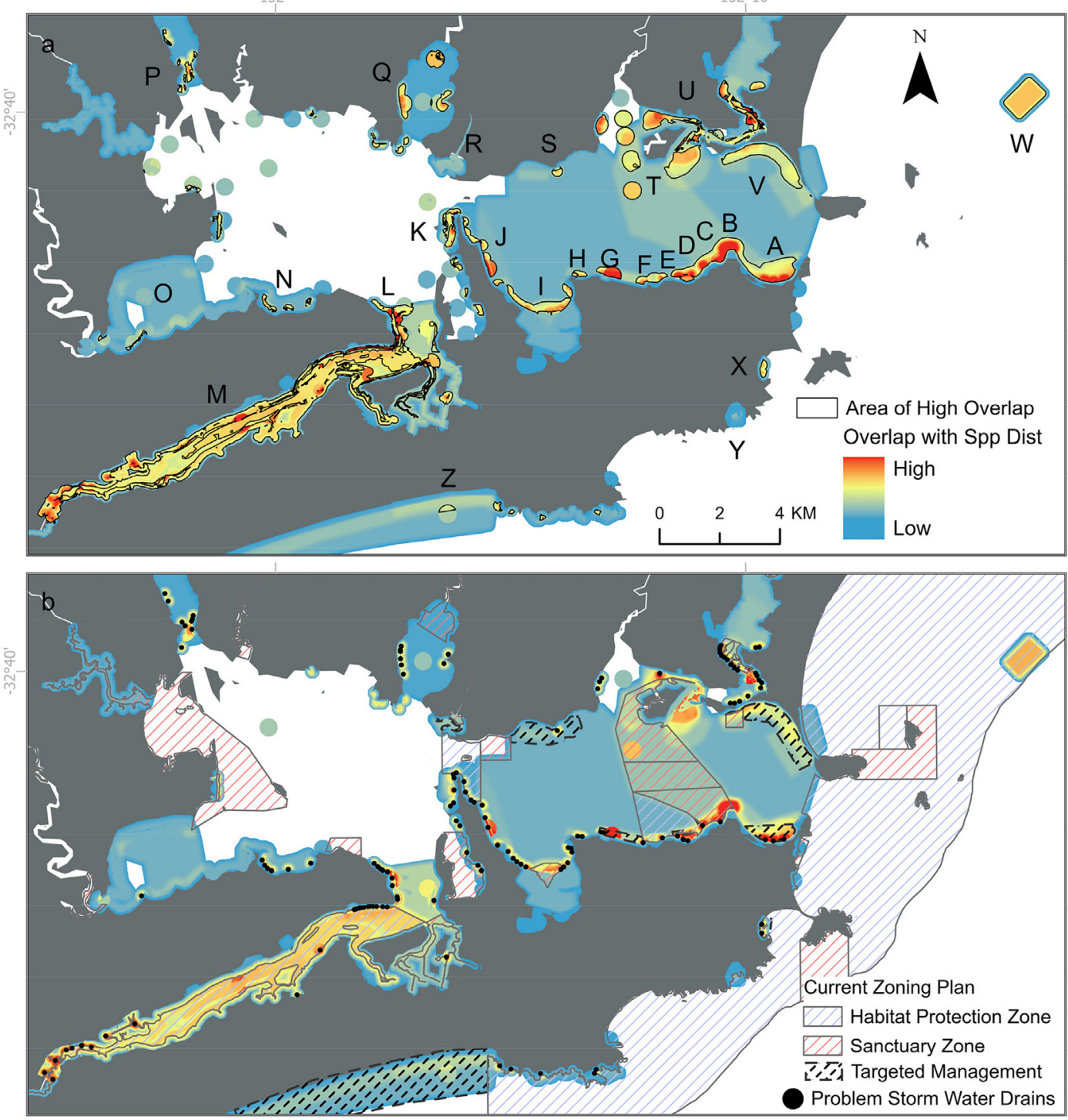

Fig. 3. Areas of stakeholder ecological concerns were combined and overlaid with the overall species distribution map (Fig. 2d) to identify areas at risk. High-value overlap areas were explored in two ways: (a) area of high overlap were outlined with intersecting polygons and then identified with a letter, which is examined in Appendix A, Table A3; and (b) areas were overlaid with the current zoning plan to identify areas that would benefit from targeted management using a variety of methods and to highlight potential problem storm water drains. Note: Stockton Beach (south ocean beach) is currently not part of the PSGLMP zoning plan but was identified to be socially significant for species and concerns.

importance to the community will not only work to protect species that will be experiencing this pressure but also has the potential to engender more community support for the MPA since it will be functioning to protect locally iconic species.

There is a common argument that spatial management has limitations in protecting non-resident fish species that are highly mobile and migratory (Roberts and Sargant, 2002), thereby highlighting the limitations of spatial management on restricted sections of coastline. Indeed, this was a common response when questioning the scientists and managers about the lack of attention towards some of the iconic species in the area for both priorities in monitoring and spatial management (both fisheries targets and non-extractive species; Table 1). Certainly, the Aboriginal Traditional Owners, commercial and recreational fishers often voiced this sentiment as a limitation of the current spatial plan in protecting and supporting some of the fishery target species, and in a couple of cases, suggested that this should be the basis for abandoning the spatial plan altogether. On the contrary, some of the other tourism and community stakeholder groups noted that when diving/snorkelling in the no-take areas the highly mobile fisheries species (e.g., bream) were in high numbers compared to other areas without fishing protection. An emerging set of data in the PSGLMP (Fulton et al., 2016; Harasti et al., 2018), suggests that there are increases in the abundance of these types of fisheries species in the PSGLMP no-take zones, which supports these T/LEK perceptions.

To further dispel these common misconceptions, there is a growing body of evidence that demonstrates strategically placed spatial fisheries closures have the capacity to protect mobile and migratory species (Claudet et al., 2010; Gell and Roberts, 2003; Roberts and Sargant, 2002) and can help to meet connectivity targets (Dunn et al., 2019). All of these species (except marlin) have habitat requirements at different life stages (Table 1), which can be met and included in the intention of spatial planning. Other spatial considerations are needed since most of the species have small home ranges, high site fidelity, and preferred foraging and resting areas within the MPA (when not migrating), which fit well within the spatial footprint of the MPA $\left(0.5-40 \mathrm{~km}^{2}\right.$ ranges within $980 \mathrm{~km}^{2}$ MPA area; Table 1). During migration periods for these fish, turtles, and mammals, there are spatial considerations of potential bottlenecks in the migration corridors, spawning aggregation sites, and 
Table 1

Data substantiating how spatial management can support iconic mobile and migratory species by demonstrating the habitat requirements at certain life history stages (e.g. nursery habitat for juveniles), spatial scale considerations, and key knowledge gaps for species originally discounted by local management. More site-attached iconic species that have received conservation and management attention (e.g., Snapper, Blue Groper) are not included in the table below.

\begin{tabular}{ll}
\hline Iconic species & Habitat requirements \\
\hline $\begin{array}{c}\text { Blue swimmer crabs (Portunus } \\
\text { armatus) }\end{array}$ & $\begin{array}{l}\text { Forage in seagrass and on sand flats (Edgar, } \\
\text { 1990) and also associated with mangroves } \\
\text { and saltmarsh (Taylor et al., 2018b). }\end{array}$ \\
Bream (Acanthopagrus australis) & $\begin{array}{l}\text { Commonly found in seagrass, mangroves, } \\
\text { saltmarshes, kelp, soft coral, and rocky reefs } \\
\text { (Curley et al., 2013; Poulos et al., 2013; } \\
\text { Saintilan et al., 2007). }\end{array}$ \\
\end{tabular}

Dolphins (Delphinus delphis, Tursiops aduncus)

Grey Nurse Shark (Carcharias taurus)

Great White Shark (Carcharodon carcharias)

Marlin (Istiompax indica, Kajikia audax, Makaira mazara)

Mullet (Mugil cephalus, Myxus elongates)

Mulloway (Argyrosomus japonicas)

Sea turtles (Chelonia mydas, Caretta caretta, Eretmochelys imbricate)

Tailor (Pomatomus saltatrix)

\section{Whales (Megaptera} novaeangliae)

Whiting (Sillago ciliata Sillago flindersi, Sillago maculate, Sillago robusta) pelagic feeders that are controlled by abiotic factors (Filby et al., 2010).

Forage and resting sites on rocky reefs surrounding inshore islands (Otway and Ellis, 2011).

Juveniles regularly found in the PSGLMP estuary in shallow areas (Harasti et al., 2017) and offshore beaches (Bruce and Bradford, 2011).

Highly pelagic species that are capture associated with sea surface temperatures of 22-24 ${ }^{\circ} \mathrm{C}$ (Ortega-García et al., 2003).

Mugil cephalus forage on seagrass and mud flats (Whitfield et al., 2012).

Juveniles prefer deeper waters in estuaries with significant freshwater flows and adults are found mostly in lower parts of estuaries, surf zones, and rocky reefs (Silberschneider and Gray, 2008; Taylor et al., 2006).

C. mydas forage on seagrass, green, brown, and red algae. C. caretta forage on bivalves (sand/reef/mud), anemones (sand/reef), and blue swimmer crabs (seagrass). E. imbricate sponge and algae (reef) (Bjornclal, 2017) Juveniles use estuary seagrass, algae, mud and oyster bed for foraging (Shepherd and Packer, 2006) and adults use estuaries and beaches as foraging areas (Shepherd and Packer, 2006)

Shallow estuaries on the east coast of Australia are known resting grounds for directly north and south of the estuary entrances (Bruce et al., 2014) and juveniles (Burchmore et al., 1988; Smith and Sinerchia, 2004)
Spatial considerations

Estuary species with spawning aggregations at the entrance of estuaries (Kangas, 2000; Sumpton et al., 2003).

High site fidelity and forage near home sites in $\sim 0.5 \mathrm{~km}^{2}$ areas (Taylor et al., 2018a), tagging recapture studies find majority are recaptured in same estuary, and spawning migrations result in aggregations at estuary entrances and coastal beaches (Roberts and Ayre, 2010).

T. aduncus estuary populations have site fidelity and small home ranges $\left(40.4 \pm 16.8 \mathrm{~km}^{2}\right)$ (Fury and Harrison, 2008; Gubbins, 2002; Sprogis et al., 2016). Delphinus delphis have high site fidelity within a $50 \mathrm{~km}^{2}$ area (Mason et al., 2016) mother and calf and non-calf pods, especially

Forage on seagrass, sand, mud for both adults
Aggregation resting sites in rocky reef gutters, overhangs, and caves around inshore islands (Otway and Ellis, 2011).

Juveniles demonstrate temporary residency

towards preferred sites and habitat areas (Bruce et al., 2019; Bruce and Bradford, 2011; Harasti et al., 2017)

Migrate from tropical spawning areas to subtropical feeding grounds (Kopf et al., 2012). All three are highly mobile species but aggregated offshore of PSGLMP as supported by significant recreational and commercial fishing effort.

Mostly an estuary species with small home ranges $(5 \mathrm{~km})$ and site fidelity, but spawning migrations/aggregations occur offshore (Whitfield et al., 2012)

Mostly an estuarine species that have high site fidelity with home ranges of $6-17 \mathrm{~km}^{2}$

(depending on fish length) (Taylor et al., 2006) especially with juveniles (majority of recaptures within $3 \mathrm{~km}$ of tag site) and has spawning aggregations offshore

All three sea turtles have distinct home ranges $\left(7.3 \pm 3.03 \mathrm{~km}^{2}\right)$ both at juvenile and adult stages (Gaos et al., 2012; Makowski et al., 2006; Schofield et al., 2013; Seminoff et al., 2002; Van Dam and Diez, 1998)

Juveniles and adults have high site fidelity with high recapture rates in estuaries (Able et al., 2003) and high recapture rates across a $\sim 10 \mathrm{~km}^{2}$ area (Morton et al., 1993)

Nearshore migration corridor within the PSGLMP (Andrews-Goff et al., 2018; Australian Antarctic Data Centre, 2010; Gales et al., 2009).

Juveniles recruit to seagrass beds and adults spawn at the mouth of estuaries and in surf zones (Smith and Sinerchia, 2004).
Data needs

Very data poor species. Need to understand home ranges and verify spawning aggregations. LEK of spawning aggregation site for the PSGLMP added to the SDM Fig. 2.

Need to understand spawning migration corridors and aggregation behaviours. LEK and scientific data added to the SDM Fig. 2 .

Need more offshore sighting data needed for $D$. delphis, which could be gathered from citizen science teams could be collated to find core areas. Some T. aduncus sighting data from citizen science groups has been added to SDM Fig. 2 .

Core aggregation sites known for PSGLMP (Otway and Ellis, 2011) and added to the SDM Fig. 2.

Satellite and acoustic tracking data already collected for PSGLMP (Bruce and Bradford, 2012, 2011; Harasti et al., 2017) and added to the SDM Fig. 2

Very data poor species. Need satellite tracking data for the PSGLMP area for all three species, along with more recreational and commercial catch data locations. Some LEK and scientific data added to SDM Fig. 2.

Need to understand home ranges, habitat preferences, and spawning migrations. Some LEK of migration bottlenecks locations identified and added to SDM Fig. 2.

Need to understand home ranges in the PSGLMP and verify spawning aggregation sites. LEK of spawning aggregation site was added to SDM Fig. 2.

Spatial tracking data for all three species already collected for PSGLMP and added to the SDM Fig. 2.

Very data poor species. Migrations and spawning locations that are unknown on NSW coastline (Miskiewicz et al., 1996). Need to identify spawning aggregation sites.

Citizen sighting data could be used to find the resting areas (Bruce et al., 2014). Migratory pathways have been added to SDM Fig. 2.

Very data poor species. Need to identify home ranges, site fidelity, and spawning aggregation sites. migration foraging/resting areas (Table 1 ) and will be taking place in the abutting Commonwealth Hunter Marine Park only $3 \mathrm{~nm}$ offshore from PSGLMP (Australian Marine Parks, 2019). Importantly, these spatial uses by mobile and migratory species is also an important consideration when rolling back spatial protection of beaches (see methods section) since many of these species utilise these areas during migrations, foraging, and for spawning (Table 1). As suggested by the scientists and managers, the main reason for the lack of protection is the paucity of localised spatial data for these species. However, many of these areas were identified as part of the T/LEK species distribution models developed in this study or has been collected by the scientists and government departments, but not utilised. Importantly, this spatial dataset could act as a starting point for prioritising scientific research on these species, especially on the data-poor species. Overall, using the precautionary approach (Agardy, 1994) suggests that protecting these species should be a priority in whatever capacity using all the available evidence since addressing stakeholder concerns will help to build trust and voluntary compliance within the MPA management. 


\subsection{Using stakeholder ecological concerns for coordinated and targeted management}

Given marine environments are dynamic ecosystems, MPAs are not in isolation from the surrounding environment or ongoing cross-system threats (Allison et al., 1998; Álvarez-Romero et al., 2011; Stoms et al., 2005). All the stakeholders in this study were particularly aware of the ecological impacts of land-sea connections, more so than being concerned with in-water threats to their marine environment. These landsea connections were mostly involving impacts of poor water quality, with the majority of the threats perceived not to come from freshwater inputs, but from primary terrestrial sources. Likewise, other studies have identified that land-sea connections are necessary considerations in Marine Protected Areas, but often not part of the conservation planning and management (Cicin-Sain and Belfiore, 2005), or have acknowledge the scale and impact of land-based threats (Halpern et al., 2009). Though the evidence of the scientists and managers regarding of land-sea connections is inclusive, due to the poor response rates, many of the agencies interviewed here acknowledged there are many levels of different institutions working within the same place and were also aware of the overall lack of necessary coordination to minimise threats to the MPA (for example see Manager and Scientist Responses to Water Quality in Appendix A, Table A2). Using combinatory mapping techniques (Coll et al., 2012; Doran and Burgess, 2012), as outlined in this paper, provides a logical means of highlighting the need for coordinated efforts across the different agencies with the capacity to work together on key areas identified having the most significant impact on iconic species and biodiversity. For example, a surprising outcome of the study was the imperative participation of the land councils in minimising these land-sea connections through managing terrestrial inputs such as litter, stormwater, septic system monitoring, development runoff, erosion control, and ways they could be exacerbating or mitigating sand movements (e.g., installing boat ramps, beach sand replenishment initiatives). These impacts, in particular, were perceived by the stakeholders to be some of the most significant ecological threats to the MPA and were thought to have the potential to destroy livelihoods, damage critical iconic habitats, and reduce cultural and community wellbeing. Therefore, developing better coordination and prioritisation of these issues is essential in supporting the community and ecological resilience of the MPA.

Prioritising stakeholder concerns within an MPA has the potential to meet multiple adaptive co-management criteria since governance of natural resources often requires coordination and partnerships with stakeholders to deal with limitations of a single top-down management agency (Berkes, 2009). Creating a level of knowledge exchange and networking with the stakeholders is the start of developing co-management strategies (Berkes, 2009; Folke et al., 2005), which can help to bridge multiple organisations and to co-produce knowledge of the dynamic social-ecological MPAs systems. A co-managed system of coordinated management across agencies is a way to facilitate ongoing collaboration and feedbacks, build trust across stakeholders and decision-makers, and create a strategic management system to meet ongoing demands (Berkes, 2009; Folke et al., 2005). However, the managers and scientists here, even with a low response rate, had a general mismatch of priorities with the threat management within the MPA and even a level of scepticism of the stakeholders' knowledge and concerns. The lack of responses could be representative of many things, such as not being comfortable in making comments that may misrepresent the Governments or Ministers agenda, not wanting to identify the lack of resources and staff to address ongoing issues in the area, and having the need to prioritise more urgent management areas outside the MPA. Using climate change as an example, this was not mentioned during any of the interviews within these groups and when asked, in some instances was discounted by the government scientists and mangers (aligning with the current ministerial positions) as a threat to the marine ecosystems. However, it was a concern with some of the stakeholders in the study and has been identified as a significant threat to local habitats and iconic fish species (Vergés et al., 2014; Wernberg et al., 2013).

Scepticism and lack of prioritisation of local and Indigenous knowledge by scientists and managers is an issue (Berkes, 2009; Bundy and Davis, 2013), even though other studies have found this to be successful way of understanding changes in the marine environment due to ongoing threats (Aswani et al., 2015; Lemahieu et al., 2018), as sources of traditional adaptive resource management based on longterm feedback learning (Berkes et al., 2000; Gadgil et al., 1993), and as a way to better socially adapt to climate change (Leonard et al., 2013; Turner and Spalding, 2013). Ultimately, developing methods to combine this information with scientific monitoring and management priorities is critical since local people may be less aware of slower changes to the environment (Aswani et al., 2015). To start this process, the methods presented in this paper, can help to open the lines of communication between the scientists and managers using maps to address the concerns of the stakeholder groups' by discussing how the marine ecosytems are being currently being managed. Also, the mapping outputs could also be used as starting points to help develop more trusting working relationships with the stakeholders that could facilitate adaptive co-management strategies and ongoing knowledge exchanged within the dynamic socio-ecological systems of MPAs.

\section{Conclusions}

Stakeholders use and value marine environments within an MPA in many different ways. In this study, it was found that the central driver for many stakeholders in interacting with these environments is accessing and enjoying marine species in extractive and non-extractive ways. Using a process of participatory sketch-mapping provides a method that can be used to identify hotspot locations that stakeholders' regularly use to access these species, known areas that support species persistence, and identify areas of ecological threats. Combining this information with scientific studies using GIS fuzzy-set spatial modelling approaches, provides a technique to develop species distributions models that identify gaps in spatial understanding and highlights areas that need targeted management. Developing this level of strategic spatial understanding across MPAs provides a way to develop readily accessible outputs that can be used by both decision-makers and stakeholders to understand, discuss, and adapt marine spatial management approaches that support both social and ecological priorities.

\section{Author contributions}

Mae M. Noble Conceptualization, Methodology, Software, Formal Analysis, Investigation, Writing - original draft, Visualization, Funding Acquisition. David Harasti Resources, Supervision, Writing - review \& editing, Validation. Christopher J. Fulton Resources, Writing - review \& editing, Validation. Bruce Doran Project administration, Conceptualization, Resources, Supervision, Writing - review \& editing, Validation.

\section{Declaration of competing interest}

We confirm that this data and manuscript have not been published in any other journal, nor are under consideration elsewhere. We have no conflicts of interest to declare. All authors agree with the contents of the manuscript and its submission to the Biological Conservation. The research was conducted under the preapproval, and continuous monitoring of a full human ethics review through The Australian National University. The funding sources have been identified in a separate section to the acknowledgements and will not have any direct financial benefits resulting from publication. 


\section{Acknowledgements}

We would like to acknowledge the Worimi Traditional Custodians of the lands and sea upon which this research was conducted, and pay respects to their Elders past, present, and future. We would like to thank all the participants in this study: D. Aldrich, J. Alessi, M. Angle, T. Blackett, J. Booth, C. Bridgeman, C. Bridgeman, M. Carter, E. Challen, R. Chick, J. Clarke, V. Cole, M. Colecliffe, D. Cruz, T. Davis, G. Davison, D. Dawson, N. Dique, T. Domico, J. Drinkwater, A. Faulkner, G. Finn, F. Future, T. Glasby, E. Glen, G. Grainger, B. Hancock, S. Harlor, J. Harris, P. Hearfield, M. Hogg, B. Horn, R. Horsfield, D. Hume, M. Hunter, M. Lamond, W. Lamond, R. Lilley, L. Lukin, A. MacDonald, T. Mackay, B. Manton, K. Manton, W. Mayer, K. McIntosh, L. McIntosh, T. Meharg, J. Nell, R. Nyquist, M. O'Connor, B. Pease, T. Pease, M. Phelps, T. Platt, J. Power, L. Pratt, R. Reeder, C. Ridgeway, L. Roberts, G. Russell, D. Scott, J. Simpson, M. Smith, P. Tucker, P. Viera, I. Watt, and S. Webb, as well as those who did not want to disclose their identity. Thank you to the Marine Parks Association for sharing the dolphin census dataset. Thank you to Rose and Wallace Capp for the support during fieldwork. All interviews were conducted under assessment and pre-approval by the Australian National University Human Ethics Committee (Permit \#2016/333) and New South Wales Department of Primary Industries, Marine Parks Permit \#2016/008.

\section{Funding sources}

Thank you to the Lesslie Research Scholarship in Landscape Conservation and Ecology grant, the Fenner School of Environment and Society, Australian National University, and the Australian Government Research Training Program Scholarship for funding this research project.

\section{Appendix A. Supplementary data}

Supplementary data to this article can be found online at https:// doi.org/10.1016/j.biocon.2020.108709.

\section{References}

Able, K.W., Rowe, P., Burlas, M., Byrne, D., 2003. Use of ocean and estuarine habitats by young-of-year bluefish (Pomatomus saltatrix) in the New York Bight. Fish. Bull. 101, 201-214.

Adriaenssens, V., Goethals, P.L.M., De Pauw, N., 2006. Fuzzy knowledge-based models for prediction of Asellus and Gammarus in watercourses in Flanders (Belgium). Ecol. Modell. 195, 3-10. https://doi.org/10.1016/j.ecolmodel.2005.11.043.

Agardy, T.M., 1994. Advances in marine conservation: the role of marine protected areas. Trends Ecol. Evol. 9, 267-270. https://doi.org/10.1016/0169-5347(94)90297-6.

Agardy, T., Bridgewater, P., Crosby, M.P., Day, J., Dayton, P.K., Kenchington, R., Laffoley, D., McConney, P., Murray, P.A., Parks, J.E., Peau, L., 2003. Dangerous targets? Unresolved issues and ideological clashes around marine protected areas. Aquat. Conserv. Mar. Freshw. Ecosyst. 13, 353-367. https://doi.org/10.1002/aqc.583.

Airamé, S., Dugan, J.E., Lafferty, K.D., Leslie, H., Deborah, A., Mcardle, D.A., Warner, R.R., 2003. Applying ecological criteria to marine reserve design: a case study from the California Channel Islands. Ecol. Appl. 13, S170-S184. https://doi.org/10.1890/ 1051-0761(2003)013[0170:AECTMR]2.0.CO;2.

Allison, G.W., Lubchenco, J., Carr, M.H., 1998. Marine reserves are necessary but not sufficient for marine conservation. Ecol. Appl. 8, S79-S92. https://doi.org/10.2307/ 2641365.

Álvarez-Romero, J.G., Pressey, R.L., Ban, N.C., Vance-Borland, K., Willer, C., Klein, C.J., Gaines, S.D., 2011. Integrated land-sea conservation planning: the missing links. Annu. Rev. Ecol. Evol. Syst. 42, 381-409. https://doi.org/10.1146/annurev-ecolsys102209-144702.

Andrews-Goff, V., Bestley, S., Gales, N.J., Laverick, S.M., Paton, D., Polanowski, A.M., 2018. Humpback whale migrations to Antarctic summer foraging grounds through the southwest Pacific Ocean. Sci. Rep. 8, 1-14. https://doi.org/10.1038/s41598-01830748-4.

Aswani, S., Lauer, M., 2006. Benthic mapping using local aerial photo interpretation and resident taxa inventories for designing marine protected areas. Environ. Conserv. 33, 263-273. https://doi.org/10.1017/S0376892906003183.

Aswani, S., Vaccaro, I., Abernethy, K., Albert, S., de Pablo, J.F.L., 2015. Can perceptions of environmental and climate change in island communities assist in adaptation planning locally? Environ. Manage. 56, 1487-1501. https://doi.org/10.1007/ s00267-015-0572-3.

Atlas of Living Australia, 2019. Atlas of Living Australia. URL. https://www.ala.org.au/,
Accessed date: 29 July 2019 (WWW document).

Australian Antarctic Data Centre, 2010. Australian east coast whales. URL. https://data. aad.gov.au/aadc/argos/display_campaign.cfm?campaign_id =87, Accessed date: 2 August 2019 (WWW document)

Australian Marine Parks, 2019. Hunter Marine Park. URL. https://parksaustralia.gov.au/ marine/parks/temperate-east/hunter/, Accessed date: 7 November 2019 (WWW document).

Baldwin, K., Oxenford, H.A., 2014. A participatory approach to marine habitat mapping in the Grenadine Islands. Coast. Manag. 42, 36-58. https://doi.org/10.1080/ 08920753.2013.863725.

Bellwood, D.R., Hughes, T.P., Folke, C., Nyström, M., 2004. Confronting the coral reef crisis. Nature 429, 827-833. https://doi.org/10.1038/nature02691.

Berkes, F., 2009. Evolution of co-management: Role of knowledge generation, bridging organizations and social learning. J. Environ. Manage. 90, 1692-1702. https://doi. org/10.1016/j.jenvman.2008.12.001.

Berkes, F., Colding, J., Folke, C., 2000. Rediscovery of Traditional Ecological Knowledge as adaptive management. Ecol. Appl. 10, 1251-1262. https://doi.org/10.1890/10510761(2000)010[1251:ROTEKA]2.0.CO;2.

Bickman, L, Rog J, D, 2009. The SAGE handbook of applied social research methods. Sage Publishing, Los Angeles.

Bjornclal, K.A., 2017. Foraging ecology and nutrition of sea turtles. Biol. Sea Turtles I, 199-231. https://doi.org/10.1201/9780203737088.

Bohnsack, J.A., 1998. Application of marine reserves to reef fisheries management. Austral Ecol. 23, 298-304. https://doi.org/10.1111/j.1442-9993.1998.tb00734.x.

Boschmann, E.E., Cubbon, E., 2014. Sketch gaps and qualitative GIS: using cartographies of individual spatial narratives in geographic research. Prof. Geogr. 66, 236-248. https://doi.org/10.1080/00330124.2013.781490.

Brown, G., Fagerholm, N., 2015. Empirical PPGIS/PGIS mapping of ecosystem services: a review and evaluation. Ecosyst. Serv. 13, 119-133. https://doi.org/10.1016/j.ecoser. 2014.10.007.

Brown, G.G., Pullar, D.V., 2012. An evaluation of the use of points versus polygons in public participation geographic information systems using quasi-experimental design and Monte Carlo simulation. Int. J. Geogr. Inf. Sci. 26, 231-246. https://doi.org/10. 1080/13658816.2011.585139.

Bruce, B.D., Bradford, R.W., 2011. Near-Shore Habitat Use by Juvenile White Sharks in Coastal Waters Off Port Stephens. Hobart.

Bruce, B.D., Bradford, R.W., 2012. Habitat use and spatial dynamics of juvenile white sharks, Carcharodon carcharias, in Eastern Australia. In: Domeier, M. (Ed.), Global Perspectives on the Biology and Life History of the White Shark. CRC Press, Boca Raton, pp. 225-254.

Brown, G, Strickland-Munro, J, Kobryn, H, Moore A, S, 2017. Mixed methods participatory GIS: an evaluation of the validity of qualitative and quantitative mapping methods. Appl. Geogr. 79, 153-166. https://doi.org/10.1016/j.apgeog.2016.12.015.

Bruce, E., Albright, L., Sheehan, S., Blewitt, M., 2014. Distribution patterns of migrating humpback whales (Megaptera novaeangliae) in Jervis Bay, Australia: a spatial analysis using geographical citizen science data. Appl. Geogr. 54, 83-95. https://doi.org/10. 1016/j.apgeog.2014.06.014.

Bruce, B.D., Harasti, D., Lee, K., Gallen, C., Bradford, R., 2019. Broad-scale movements of juvenile white sharks Carcharodon carcharias in eastern Australia from acoustic and satellite telemetry. Mar. Ecol. Prog. Ser. 619, 1-15. https://doi.org/10.3354/ meps12969.

Bryman, A, 2016. Social research methods. Oxford University Press, New York.

Buckley, R., 2010. Adventure Tourism Management, International Centre for Ecotourism Research. Butterworth-Heinemann Elsevier, Oxford. https://doi.org/10.4324/ 9781856178358.

Bundy, A., Davis, A., 2013. Knowing in context: an exploration of the interface of marine harvesters' local ecological knowledge with ecosystem approaches to management. Mar. Policy 38, 277-286. https://doi.org/10.1016/j.marpol.2012.06.003.

Burchmore, J.J., Pollard, D.A., Middleton, M.J., Bell, J.D., Pease, B.C., 1988. Biology of four species of whiting (Pisces:Sillaginidae) in botany bay, New South Wales. Mar. Freshw. Res. 39, 709-727. https://doi.org/10.1071/MF9880709.

Burrough, P.A., McDonnell, R.A., 2000. Principles of Geographical Information Systems. Oxford University Press, New York.

Caro, T., 2010. Conservation by Proxy: Indicator, Umbrella, Keystone, Flagship, and Other Surrogate Species. Island Press, Washington DC.

Cicin-Sain, B., Belfiore, S., 2005. Linking marine protected areas to integrated coastal and ocean management: a review of theory and practice. Ocean Coast. Manag. 48, 847-868. https://doi.org/10.1016/j.ocecoaman.2006.01.001.

Claudet, J., Osenberg, C.W., Domenici, P., Badalamenti, F., Milazzo, M., Falcón, J.M., Bertocci, I., Benedetti-Cecchi, L., García-Charton, J.A., Goni, R., Borg, J.A., Forcada, A., De Lucia, G.D., Pérez-Ruzafa, Á., Afonso, P., Brito, A., Guala, I., Le Diréach, L., Sanchez-Jerez, P., Somerfield, P.J., Planes, S., 2010. Marine reserves: fish life history and ecological traits matter. Ecol. Appl. 20, 830-839. https://doi.org/10.1890/082131.1.

Coll, M., Piroddi, C., Albouy, C., Ben Rais Lasram, F., Cheung, W.W.L., Christensen, V., Karpouzi, V.S., Guilhaumon, F., Mouillot, D., Paleczny, M., Palomares, M.L., Steenbeek, J., Trujillo, P., Watson, R., Pauly, D., 2012. The Mediterranean Sea under siege: spatial overlap between marine biodiversity, cumulative threats and marine reserves. Glob. Ecol. Biogeogr. 21, 465-480. https://doi.org/10.1111/j.1466-8238. 2011.00697.x.

Costa, H., Ponte, N.B., Azevedo, E.B., Gil, A., 2015. Fuzzy set theory for predicting the potential distribution and cost-effective monitoring of invasive species. Ecol. Modell. 316, 122-132. https://doi.org/10.1016/j.ecolmodel.2015.07.034.

Cribb, N., Miller, C., Seuront, L., 2013. Indo-Pacific bottlenose dolphin (Tursiops aduncus) habitat preference in a heterogeneous, urban, coastal environment. Aquat. Biosyst. 9, 1-9. https://doi.org/10.1186/2046-9063-9-3. 
Crowder, L., Norse, E., 2008. Essential ecological insights for marine ecosystem-based management and marine spatial planning. Mar. Policy 32, 772-778. https://doi.org/ 10.1016/j.marpol.2008.03.012.

Curley, B.G., Jordan, A.R., Figueira, W.F., Valenzuela, V.C., 2013. A review of the biology and ecology of key fishes targeted by coastal fisheries in south-east Australia: identifying critical knowledge gaps required to improve spatial management. Rev. Fish Biol. Fish. 23, 435-458. https://doi.org/10.1007/s11160-013-9309-7.

Davis, A, Wagner R, J, 2003. Who knows? On the importance of identifying "experts" when researching local ecological knowledge. Human Ecology 31, 463-489. https:// doi.org/10.1023/A:1025075923297.

Doran, B.J., Burgess, M.B., 2012. Putting Fear of Crime on the Map. Springer, New York.

Doran, B., Young, M., 2013. Assessing the impact of a remote area casino: a mixedmethods approach using cognitive mapping and GIS. Rural Soc. 23, 20-31. https:// doi.org/10.5172/rsj.2013.23.1.20.

Douvere, F., 2008. The importance of marine spatial planning in advancing ecosystembased sea use management. Mar. Policy 32, 762-771. https://doi.org/10.1016/j. marpol.2008.03.021.

Dunn, D.C., Harrison, A.-L., Curtice, C., Appeltans, W., Bailey, H., Ballance, L., Block, B., Boustany, A., Brenner, J., Corkeron, P., Costa, D.P., Crespo, G.O., Davies, T., DeLand, S., Dias, M., Donnelly, B., Douvere, F., Ferretti, F., Freestone, D., Frisch-Nwakanma, H., Froján, C.B., Fujioka, E., Gjerde, K.M., Glowka, L., Godley, B.J., Gunn, V., Hays, G.C., Hazien, C., Heywood, E., Jimenez, J., Johnson, D.E., Kot, C.Y., Maxwell, S., di Sciara, G.N., Palacios, D.M., Pauly, A., Salazar, E.R., Secor, D., Sequiera, A., Spalding, M., Spina, F., Van Parijs, S., Wallace, B., Virtue, M., Weimerskirch, H., Woodward, B., Alberini, A., Blondin, H., Poulin, S., Cleary, J., Halpin, P.N., 2019. The importance of migratory connectivity to global ocean policy. Proc. R. Soc. B 286, 20191472-20191482. https://doi.org/10.1098/rspb.2019.1472.

Eastman, J., 1999. Multi-criteria evaluation and GIS. In: Goodchild, M.F., Maguire, D.J., Rhind, D.W. (Eds.), Geographical Information Systems. John Wiley and Sons, New York, pp. 493-502.

Edgar, J., 1990. Predator-prey interactions in seagrass beds. II. Distribution and diet of the blue manna crab Portunus pelagicus Linnaeus at Cliff Head, Western Australia. 139, 23-32.

Edgar, G.J., Stuart-Smith, R.D., 2019. Reef Life Survey (RLS). URL. https://reeflifesurvey imas.utas.edu.au/portal/search, Accessed date: 25 June 2019 (WWW document).

Elith, J., Leathwick, J.R., 2009. Species distribution models: ecological explanation and prediction across space and time. Annu. Rev. Ecol. Evol. Syst. 40, 677-697. https:// doi.org/10.1146/annurev.ecolsys.110308.120159.

Fernandes, L., Day, J., Lewis, A., Slegers, S., Kerrigan, B., Breen, D., Cameron, D., Jago, B., Hall, J., Lowe, D., Innes, J., Tanzer, J., Chadwick, V., Thompson, L., Gorman, K., Simmons, M., Barnett, B., Sampson, K., De'ath, G., Mapstone, B., Marsh, H., Possingham, H., Ball, I., Ward, T., Dobbs, K., Aumend, J., Slater, D., Stapleton, K., 2005. Establishing representative no-take areas in the great barrier reef: large-scale implementation of theory on marine protected areas. Conserv. Biol. 19, 1733-1744. https://doi.org/10.1111/j.1523-1739.2005.00302.x.

Filby, N.E., Bossley, M., Sanderson, K.J., Martinez, E., Stockin, K.A., 2010. Distribution and population demographics of common dolphins (Delphinus delphis) in the Gulf St. Vincent, South Australia. Aquat. Mamm. 36, 33-45. https://doi.org/10.1578/AM.36. 1.2010 .33 .

Foley, M.M., Halpern, B.S., Micheli, F., Armsby, M.H., Caldwell, M.R., Crain, C.M., Prahler, E., Rohr, N., Sivas, D., Beck, M.W., Carr, M.H., Crowder, L.B., Emmett Duffy, J., Hacker, S.D., McLeod, K.L., Palumbi, S.R., Peterson, C.H., Regan, H.M., Ruckelshaus, M.H., Sandifer, P.A., Steneck, R.S., 2010. Guiding ecological principles for marine spatial planning. Mar. Policy 34, 955-966. https://doi.org/10.1016/j. marpol.2010.02.001.

Folke, C., Hahn, T., Olsson, P., Norberg, J., 2005. Adaptive governance of social-ecological systems. Annu. Rev. Environ. Resour. 30, 441-473. https://doi.org/10.1146/ annurev.energy.30.050504.144511.

Franklin, J., 2010. Mapping Species Disturbutions. Cambridge University Press, Cambridge.

Fulton, C.J., Noble, M.N., Radford, B., Gallen, C., Harasti, D., 2016. Microhabitat selectivity underpins regional indicators of fish abundance and replenishment. Ecol. Indic. 70, 222-231. https://doi.org/10.1016/j.ecolind.2016.06.032.

Fury, C.A., Harrison, P.L., 2008. Abundance, site fidelity and range patterns of IndoPacific bottlenose dolphins (Tursiops aduncus) in two Australian subtropical estuaries. Mar. Freshw. Res. 59, 1015-1027. https://doi.org/10.1071/MF08109.

Gadgil, M., Berkes, F., Folke, C., 1993. Indigenous knowledge for biodiveristy conservation. Ambio 22, 151-156. https://doi.org/10.1038/s41893-019-0341-z.

Gales, N., Double, M.C., Robinson, S., Jenner, C., Jenner, M., Gedamke, J., Childerhouse, S., Paton, D., 2009. Satellite Tracking of Australian Humpback (Megaptera novaeangliae) and Pygmy Blue Whales (Balaenoptera musculus brevicauda). United Kingdom.

Game, E.T., Lipsett-moore, G., Hamilton, R., Peterson, N., Kereseka, J., Atu, W., Watts, M., Possingham, H., 2011. Informed opportunism for conservation planning in the Solomon Islands. Conserv. Lett. 4, 38-46. https://doi.org/10.1111/j.1755-263X. 2010.00140.x.

Gaos, A.R., Lewison, R.L., Wallace, B.P., Yañez, I.L., Liles, M.J., Nichols, W.J., Baquero, A., Hasbún, C.R., Vasquez, M., Urteaga, J., Seminoff, J.A., 2012. Spatial ecology of critically endangered hawksbill turtles Eretmochelys imbricata: implications for management and conservation. Mar. Ecol. Prog. Ser. 450, 181-194. https://doi.org/10. 3354/meps09591.

Garcia, A., Jorde, K., Habit, E., Caamano, D., Parra, O., 2011. Downstream environmental effects of dam operations: changes in habitat quality for native fish species. River Res. Appl. 27, 312-327. https://doi.org/10.1002/rra.

Gell, F.R., Roberts, C.M., 2003. Benefits beyond boundaries: the fishery effects of marine reserves. Trends Ecol. Evol. 18, 448-455. https://doi.org/10.1016/S0169-5347(03)
00189-7.

Golledge G, R, Stimson J, R, 1997. Spatial behavior: A geographic perspective. Guilford Press, New York.

Gubbins, C., 2002. Use of home ranges by resident bottlenose dolphins (Tursiops truncatus) in a South Carolina Estuary. J. Mammal. 83, 178-187. https://doi.org/10. 1644/1545-1542(2002)083<0178:uohrbr>2.0.co;2.

Guisan, A., Thuiller, W., 2005. Predicting species distribution: offering more than simple habitat models. Ecol. Lett. 8, 993-1009. https://doi.org/10.1111/j.1461-0248.2005. 00792.x.

Halpern, B.S., 2003. The impact of marine reserves: do reserves work and does reserve size matter? Ecol. Appl. 13, S117-S137.

Halpern, B.S., Ebert, C.M., Kappel, C.V., Madin, E.M.P., Micheli, F., Perry, M., Selkoe, K.A., Walbridge, S., 2009. Global priority areas for incorporating land-sea connections in marine conservation. Conserv. Lett. 2, 189-196. https://doi.org/10.1111/j. 1755-263x.2009.00060.x.

Harasti, D., Lee, K., Bruce, B., Gallen, C., Bradford, R., 2017. Juvenile white sharks Carcharodon carcharias use estuarine environments in south-eastern Australia. Mar. Biol. 164, 1-14. https://doi.org/10.1007/s00227-017-3087-z.

Harasti, D., Williams, J., Mitchell, E., Lindfield, S., Jordan, A., 2018. Increase in relative abundance and size of snapper Chrysophrys auratus within partially-protected and notake areas in a temperate marine protected area. Front. Mar. Sci. 5, 1-12. https://doi. org/10.3389/fmars.2018.00208.

Hattab, T., Ben Rais Lasram, F., Albouy, C., Sammari, C., Romdhane, M.S., Cury, P. Leprieur, F., Le Loc'h, F., 2013. The use of a predictive habitat model and a fuzzy logic approach for marine management and planning. PLoS One 8, e76430. https:// doi.org/10.1371/journal.pone.0076430.

Hay, I., 2010. Qualitative Research Methods in Human Geography, third. ed. Oxford University Press, Ontario.

Hernandez, P.A., Graham, C.H., Master, L.L., Albert, D.L., The, A.D.L., 2006. The effect of sample size and species characteristics on performance of different species distribution modeling methods. Ecography (Cop.). 29, 773-785.

Jiang, H., Eastman, J.R., 2000. Application of fuzzy measures in multi-criteria evaluation in GIS. Int. J. Geogr. Inf. Sci. 14, 173-184. https://doi.org/10.1080/ 136588100240903

Kangas, M.I., 2000. Synopsis of the biology and exploitation of the blue swimmer crab, Portunus pelagicus Linnaeus, in Western Australia. In: Fisheries Research Report.

Kopf, R.K., Davie, P.S., Bromhead, D.B., Young, J.W., 2012. Reproductive biology and spatiotemporal patterns of spawning in striped marlin Kajikia audax. J. Fish Biol. 81 1834-1858. https://doi.org/10.1111/j.1095-8649.2012.03394.x.

Lemahieu, A., Scott, L., Malherbe, W.S., Mahatante, P.T., Randrianarimanana, J.V., Aswani, S., 2018. Local perceptions of environmental changes in fishing communities of southwest Madagascar. Ocean Coast. Manag. 163, 209-221. https://doi.org/10. 1016/j.ocecoaman.2018.06.012.

Leonard, S., Parsons, M., Olawsky, K., Kofod, F., 2013. The role of culture and traditional knowledge in climate change adaptation: insights from East Kimberley. Australia. Glob. Environ. Chang. 23, 623-632. https://doi.org/10.1016/j.gloenvcha.2013.02. 012.

Levine, A.S., Feinholz, C.L., 2015. Participatory GIS to inform coral reef ecosystem management: mapping human coastal and ocean uses in Hawaii. Appl. Geogr. 59, 60-69. https://doi.org/10.1016/j.apgeog.2014.12.004.

Lu, C.Y., Gu, W., Dai, A.H., Wei, H.Y., 2012. Assessing habitat suitability based on geographic information system (GIS) and fuzzy: a case study of Schisandra sphenanthera Rehd. et Wils. in Qinling Mountains, China. Ecol. Modell. 242, 105-115. https://doi. org/10.1016/j.ecolmodel.2012.06.002.

Makowski, C., Seminoff, J.A., Salmon, M., 2006. Home range and habitat use of juvenile Atlantic green turtles (Chelonia mydas L.) on shallow reef habitats in Palm Beach, Florida. USA. Mar. Biol. 148, 1167-1179. https://doi.org/10.1007/s00227-0050150-y.

Malczewski, J., 1999. GIS and Multicriteria Decision Analysis. Wiley \& Sons Inc., New York. https://doi.org/10.1111/j.1538-4632.2002.tb01077.x.

Malczewski, J., 2006. GIS-based multicriteria decision analysis: a survey of the literature. Int. J. Geogr. Inf. Sci. 20, 703-726. https://doi.org/10.1080/13658810600661508.

Mason, S., Kent, C.S., Donnelly, D., Weir, J., Bilgmann, K., 2016. Atypical residency of short-beaked common dolphins (Delphinus delphis) to a shallow, urbanized embayment in south-eastern Australia. R. Soc. Open Sci. 3, 160478. https://doi.org/10. 1098/rsos.160478.

Merow, C., Smith, M.J., Silander, J.A., 2013. A practical guide to MaxEnt for modeling species' distributions: what it does, and why inputs and settings matter. Ecography 36, 1058-1069. https://doi.org/10.1111/j.1600-0587.2013.07872.x.

Miskiewicz, A.G., Bruce, B.D., Dixon, P., 1996. Distribution of tailor (Pomatomus saltatrix) larvae along the coast of New South Wales. Australia. Mar. Freshw. Res. 47, 331-336. https://doi.org/10.1071/MF9960331.

Morton, R.M., Halliday, I., Cameron, D., 1993. Movement of tagged juvenile tailor (Pomatomus saltatrix) in Moreton Bay. Queensland. Aust. J. Mar. Freshw. Res. 44, 811-816. https://doi.org/10.1071/MF9930811.

Mouton, A.M., De Baets, B., Van Broekhoven, E., Goethals, P.L.M., 2009. Prevalenceadjusted optimisation of fuzzy models for species distribution. Ecol. Modell. 220, 1776-1786. https://doi.org/10.1016/j.ecolmodel.2009.04.020.

Mouton, A.M., De Baets, B., Goethals, P.L.M., 2010. Ecological relevance of performance criteria for species distribution models. Ecol. Modell. 221, 1995-2002. https://doi. org/10.1016/j.ecolmodel.2010.04.017.

Navas, J.M., Telfer, T.C., Ross, L.G., 2011. Spatial modeling of environmental vulnerability of marine finfish aquaculture using GIS-based neuro-fuzzy techniques. Mar. Pollut. Bull. 62, 1786-1799. https://doi.org/10.1016/j.marpolbul.2011.05.019.

New South Wales Department of Primary Industries, 2018. Port Stephens - Great Lakes Marine Park. URL. https://www.dpi.nsw.gov.au/fishing/marine-protected-areas/ 
marine-parks/port-stephens-marine-park, Accessed date: 15 October 2018 (WWW document).

New South Wales Marine Parks Authority, 2010. Port Stephens - Great Lakes Marine Park Operational Plan. Sydney, Australia.

Noble, M.M., Harasti, D., Pittock, J., Doran, B., 2019. Understanding the spatial diversity of social uses, dynamics, and conflicts in marine spatial planning. J. Environ. Manage. 246, 929-940. https://doi.org/10.1016/j.jenvman.2019.06.048.

NSW Marine Estate Management Authority, 2018. Marine Estate Management Strategy 2018-2028. Nelson Bay.

Ortega-García, S., Klett-Traulsen, A., Ponce-Díaz, G., 2003. Analysis of sportfishing catch rates of striped marlin (Tetrapturus audax) at Cabo San Lucas, Baja California Sur, Mexico, and their relation to sea surface temperature. Mar. Freshw. Res. 54, 483-488. https://doi.org/10.1071/MF01258.

Otway, N.M., Ellis, M.T., 2011. Pop-up archival satellite tagging of Carcharias taurus: movements and depth/temperature-related use of south-eastern Australian waters. Mar. Freshw. Res. 62, 607-620. https://doi.org/10.1071/MF10139.

Pittman, S.J., Brown, K.A., 2011. Multi-scale approach for predicting fish species distributions across coral reef seascapes. PLoS One 6, e20583. https://doi.org/10.1371/ journal.pone.0020583.

Pittman, S.J., Christensen, J.D., Caldow, C., Menza, C., Monaco, M.E., 2007. Predictive mapping of fish species richness across shallow-water seascapes in the Caribbean. Ecol. Modell. 204, 9-21. https://doi.org/10.1016/j.ecolmodel.2006.12.017.

Potter, Sandra, Bruce, Doran, Matthews, Dean, 2016. Modelling collective Yawuru values along the foreshore of Roebuck Bay, Western Australia using fuzzy logic. Appl. Geogr. 77, 8-19. https://doi.org/10.1016/j.apgeog.2016.09.016.

Poulos, D.E., Harasti, D., Gallen, C., Booth, D.J., 2013. Biodiversity value of a geographically restricted soft coral species within a temperate estuary. Aquat. Conserv. Mar. Freshw. Ecosyst. 23, 838-849. https://doi.org/10.1002/aqc.2362.

Rees, M.J., Jordan, A., Price, O.F., Coleman, M.A., Davis, A.R., 2014. Abiotic surrogates for temperate rocky reef biodiversity: implications for marine protected areas. Divers. Distrib. 20, 284-296. https://doi.org/10.1111/ddi.12134.

Roberts, D.G., Ayre, D.J., 2010. Panmictic population structure in the migratory marine sparid Acanthopagrus australis despite its close association with estuaries. Mar. Ecol. Prog. Ser. 412, 223-230. https://doi.org/10.3354/meps08676.

Roberts, C.M., Sargant, H., 2002. Fishery benefits of fully protected marine reserves: why habitat and behavior are important. Nat. Resour. Model. 15, 487-507. https://doi. org/10.1111/j.1939-7445.2002.tb00099.x.

Roberts, C.M., Branch, G., Bustamante, R.H., Castilla, J.C., Dugan, J., Halpern, B.S., Lafferty, K.D., Leslie, H., Lubchenco, J., Mcardle, D., Ruckelshaus, M., Warner, R.R., 2003. Application of ecological criteria in selecting marine reserves and developing reserve networks selecting marine reserves and developing. Ecol. Appl. 13, 215-228. https://doi.org/10.1890/1051-0761(2003)013[0215:AOECIS]2.0.CO;2.

Robertson, M.P., Villet, M.H., Palmer, A.R., 2004. A fuzzy classification technique for predicting species' distributions: applications using invasive alien plants and indigenous insects. Divers. Distrib. 10, 461-474. https://doi.org/10.1111/j.1366-9516. 2004.00108.x.

Rodríguez, J.P., Brotons, L., Bustamante, J., Seoane, J., 2007. The application of predictive modelling of species distribution to biodiversity conservation. Divers. Distrib. 13, 243-251. https://doi.org/10.1111/j.1472-4642.2007.00356.x.

Saintilan, N., Hossain, K., Mazumder, D., 2007. Linkages between seagrass, mangrove and saltmarsh as fish habitat in the Botany Bay estuary, New South Wales. Wetl. Ecol. Manag. 15, 277-286. https://doi.org/10.1007/s11273-006-9028-0.

Salski, A., 1992. Fuzzy knowledge-based models in ecological research. Ecol. Modell. 63, 103-112. https://doi.org/10.1016/0304-3800(92)90064-L.

Schofield, G., Scott, R., Dimadi, A., Fossette, S., Katselidis, K.A., Koutsoubas, D., Lilley, M.K.S., Pantis, J.D., Karagouni, A.D., Hays, G.C., 2013. Evidence-based marine protected area planning for a highly mobile endangered marine vertebrate. Biol. Conserv. 161, 101-109. https://doi.org/10.1016/j.biocon.2013.03.004.

Seminoff, J.A., Resendiz, A., Nichols, W.J., 2002. Home range of green turtles Chelonia mydas at a coastal foraging area in the Gulf of California. Mexico. Mar. Ecol. Prog. Ser. 242, 253-265. https://doi.org/10.3354/meps242253.

Shepherd, G.R., Packer, D.B., 2006. Bluefish, Pomatomus saltatrix, Life History and Habitat Characteristics. Woods Hole, Massachusetts.

Silberschneider, V., Gray, C.A., 2008. Synopsis of biological, fisheries and aquaculturerelated information on mulloway Argyrosomus japonicus (Pisces: Sciaenidae), with particular reference to Australia. J. Appl. Ichthyol. 24, 7-17. https://doi.org/10. 1111/j.1439-0426.2007.00913.x.

Sloan, N, Doran, Bruce, Markham, Francis, Pammer, K, 2016. Does base map size and imagery matter in sketch mapping? Appl. Geogr. 71, 24-31. https://doi.org/10. 1016/j.apgeog.2016.04.001.

Smith, K.A., Sinerchia, M., 2004. Timing of recruitment events, residence periods and post-settlement growth of juvenile fish in a seagrass nursery area, south-eastern Australia. Environ. Biol. Fishes 71, 73-84. https://doi.org/10.1023/B:EBFI. 0000043154.96933.de.

Sprogis, K.R., Raudino, H.C., Rankin, R., Macleod, C.D., Bejder, L., 2016. Home range size of adult Indo-Pacific bottlenose dolphins (Tursiops aduncus) in a coastal and estuarine system is habitat and sex-specific. Mar. Mammal Sci. 32, 287-308. https://doi.org/
$10.1111 / \mathrm{mms} .12260$

Stelzenmüller, V., Lee, J., South, A., Foden, J., Rogers, S.I., 2013. Practical tools to support marine spatial planning: a review and some prototype tools. Mar. Policy 38, 214-227. https://doi.org/10.1016/j.marpol.2012.05.038.

Stevens, T., Connolly, R.M., 2004. Testing the utility of abiotic surrogates for marine habitat mapping at scales relevant to management. Biol. Conserv. 119, 351-362. https://doi.org/10.1016/j.biocon.2003.12.001.

Stoms, D.M., Davis, F.W., Andelman, S.J., Carr, M.H., Gaines, S.D., Halpern, B.S., Hoenicke, R., Leibowitz, S.G., Leydecker, A., Madin, E.M.P., Tallis, H., Warner, R.R., 2005. Integrated coastal reserve planning: making the land-sea connection. Front Ecol Env. 3, 429-436. https://doi.org/10.2307/3868659.

Sullivan, C.M., Conway, F.D.L., Pomeroy, C., Hall-Arber, M., Wright, D.J., 2015. Combining geographic information systems and ethnography to better understand and plan ocean space use. Appl. Geogr. 59, 70-77. https://doi.org/10.1016/j.apgeog. 2014.11.027.

Sumpton, W., Gaddes, S., McLennan, M., Campbell, M., Tonks, M., Good, N., Hagedoorn, W., Skilleter, G., 2003. Fisheries Biology and Assessment of the Blue Swimmer Crab (Portunus pelagicus) in Queensland, Report to the Fisheries Research and Development Corporation, Project. Australia.

Sundblad, G., Bergström, U., Sandström, A., 2011. Ecological coherence of marine protected area networks: a spatial assessment using species distribution models. J. Appl. Ecol. 48, 112-120. https://doi.org/10.1111/j.1365-2664.2010.01892.x.

Taylor, M.D., Laffan, S.D., Fielder, D.S., Suthers, I.M., 2006. Key habitat and home range of mulloway Argyrosomus japonicus in a south-east Australian estuary: finding the estuarine niche to optimise stocking. Mar. Ecol. Prog. Ser. 328, 237-247. https://doi. org $/ 10.3354 /$ meps328237.

Taylor, M.D., Becker, A., Lowry, M.B., 2018a. Investigating the functional role of an artificial reef within an estuarine seascape: a case study of yellowfin bream (Acanthopagrus australis). Estuaries and Coasts 41, 1782-1792. https://doi.org/10. 1007/s12237-018-0395-6.

Taylor, M.D., Gaston, T.F., Raoult, V., 2018b. The economic value of fisheries harvest supported by saltmarsh and mangrove productivity in two Australian estuaries. Ecol. Indic. 84, 701-709. https://doi.org/10.1016/j.ecolind.2017.08.044.

Teh, L.C.L., Teh, L.S.L., 2011. A fuzzy logic approach to marine spatial management. Environ. Manage. 47, 536-545. https://doi.org/10.1007/s00267-011-9645-0.

Teixeira, J.B., Martins, A.S., Pinheiro, H.T., Secchin, N.A., Leão de Moura, R., Bastos, A.C., 2013. Traditional Ecological Knowledge and the mapping of benthic marine habitats. J. Environ. Manage. 115, 241-250. https://doi.org/10.1016/j.jenvman.2012.11.020.

Theodoropoulos, C., Skoulikidis, N., Stamou, A., Dimitriou, E., 2018. Spatiotemporal variation in benthic-invertebrates-based physical habitat modelling: can we use generic instead of local and season-specific habitat suitability criteria? Water 10 , 1508-1534. https://doi.org/10.3390/w10111508.

Turner, N., Spalding, P.R., 2013. "We might go back to this"; drawing on the past to meet the future in northwestern North American indigenous communities. Ecol. Soc. 18, 29-40 (doi:).

Van Dam, R.P., Diez, C.E., 1998. Home range of immature hawksbill turtles (Eretmochelys imbricata (Linnaeus)) at two Caribbean islands. J. Exp. Mar. Bio. Ecol. 220, 15-24. https://doi.org/10.1016/S0022-0981(97)00080-4.

Vergés, A., Steinberg, P.D., Hay, M.E., Poore, A.G.B., Campbell, A.H., Ballesteros, E., Heck, K.L., Booth, D.J., Coleman, M.A., Feary, D.A., Figueira, W., Langlois, T., Marzinelli, E.M., Mizerek, T., Mumby, P.J., Nakamura, Y., Roughan, M., van Sebille, E., Gupta, A. Sen, Smale, D.A., Tomas, F., Wernberg, T., Wilson, S.K., 2014. The tropicalization of temperate marine ecosystems: climate-mediated changes in herbivory and community phase shifts. Proc. R. Soc. B Biol. Sci. 281, 20140846. https:// doi.org/10.1098/rspb.2014.0846.

Voogd, H., 1983. Multicriteria evaluation for urban and regional planning. Pion, London. https://doi.org/10.6100/IR102252.

Voyer, M., Gollan, N., Barclay, K., Gladstone, W., 2015. "It's part of me"; understanding the values, images and principles of coastal users and their influence on the social acceptability of MPAs. Mar. Policy 52, 93-102. https://doi.org/10.1016/j.marpol. 2014.10.027.

Wernberg, T., Smale, D.A., Tuya, F., Thomsen, M.S., Langlois, T.J., De Bettignies, T., Bennett, S., Rousseaux, C.S., 2013. An extreme climatic event alters marine ecosystem structure in a global biodiversity hotspot. Nat. Clim. Chang. 3, 78-82. https:// doi.org/10.1038/nclimate1627.

Whitfield, A.K., Panfili, J., Durand, J.D., 2012. A global review of the cosmopolitan flathead mullet Mugil cephalus Linnaeus 1758 (Teleostei: Mugilidae), with emphasis on the biology, genetics, ecology and fisheries aspects of this apparent species complex. Rev. Fish Biol. Fish. 22, 641-681. https://doi.org/10.1007/s11160-0129263-9.

Wiszniewski, J., Allen, S.J., Möller, L.M., 2009. Social cohesion in a hierarchically structured embayment population of Indo-Pacific bottlenose dolphins. Anim. Behav. 77, 1449-1457. https://doi.org/10.1016/j.anbehav.2009.02.025.

Wood, L.J., Dragicevic, S., 2007. GIS-based multicriteria evaluation and fuzzy sets to identify priority sites for marine protection. Biodivers. Conserv. 16, 2539-2558. https://doi.org/10.1007/s10531-006-9035-8. 